Oceanography and Marine Biology: An Annual Review, 2008, 46, 25-63

(C) R. N. Gibson, R. J. A. Atkinson, and J. D. M. Gordon, Editors

Taylor \& Francis

\title{
EFFECTS OF BENTHIC ALGAE ON THE REPLENISHMENT OF CORALS AND THE IMPLICATIONS FOR THE RESILIENCE OF CORAL REEFS
}

\author{
CHICO L. BIRRELL ${ }^{1}$, LAURENCE J. MCCOOK ${ }^{1,2}$, \\ BETTE L. WILLIS ${ }^{1} \&$ GUILLERMO A. DIAZ-PULIDO ${ }^{3}$ \\ ${ }^{1}$ ARC Centre of Excellence for Coral Reef Studies and School of Marine and \\ Tropical Biology, James Cook University, Townsville, QLD 4811, Australia \\ E-mail: CLBirrell@gmail.com, Bette.Willis@jcu.edu.au \\ ${ }^{2}$ Great Barrier Reef Marine Park Authority, Townsville 4810, QLD, \\ Australia, and Pew Fellowships Program in Marine Conservation \\ Corresponding Author E-mail: L.McCook@gbrmpa.gov.au \\ ${ }^{3} A R C$ Centre of Excellence for Coral Reef Studies and Centre for Marine Studies, \\ The University of Queensland, Brisbane, St. Lucia 4072, QLD, Australia \\ E-mail: g.diazpulido@uq.edu.au
}

\begin{abstract}
The ecological resilience of coral reefs depends critically on the capacity of coral populations to re-establish in habitats dominated by macroalgae. Coral reefs globally are under rapidly increasing pressure from human activities, especially from climate change, with serious environmental, social and economic consequences. Coral mortality is usually followed by colonisation by benthic algae of various forms, so that algae dominate most degraded and disturbed reefs. The capacity of coral populations to re-establish in this algal-dominated environment will depend on direct and indirect impacts of the algae on the supply of coral larvae from remnant adults, on settlement of coral larvae and on the post-settlement survival and growth of juvenile corals. The effects of benthic algae on coral replenishment vary considerably but the thick mats or large seaweeds typical of degraded reefs have predominantly negative impacts. Some algae, mostly calcareous red algae, may enhance coral settlement on healthy reefs. Algal effects on coral replenishment include reduced fecundity and larval survival, pre-emption of space for settlement, abrasion or overgrowth of recruits, sloughing or dislodgement of recruits settled on crustose algae, and changes to habitat conditions. There is a serious lack of information about these effects, which are likely to cause bottlenecks in coral recovery and significantly reduce the resilience of coral reefs.
\end{abstract}

\section{Introduction}

Globally, degradation of coral reefs due to the impacts of human activity is increasing, raising concerns for the future persistence of reefs and the social and economic goods and services they provide (Bryant et al. 1998, Wilkinson 2004, Pandolfi et al. 2005). Reefs face an increasing number, intensity and frequency of stresses and disturbances (Hughes \& Connell 1999, Karlson 1999, Hughes et al. 2003), including climatic change in particular (Hoegh-Guldberg 1999, Hoegh-Guldberg et al. 2007). Coral reefs are subject to frequent disturbances, natural or anthropogenic, such as hurricanes/cyclones, crown-of-thorns starfish outbreaks, diseases and mass bleaching of corals. Their resilience, or capacity to resist or recover from these disturbances, is critical to their long-term 
persistence and contributions to economies (McCook et al. 2001b, Hughes et al. 2007). Recent research has shown that the capacity of reefs to recover from disturbances is especially vulnerable to human impacts (McCook 1999, Hughes et al. 2003, 2007, McCook et al. 2007).

The recovery of reefs after disturbance requires the re-establishment or replenishment of coral populations, either by regrowth of surviving coral fragments or the arrival and settlement of coral larvae and their post-settlement growth and survival (Hughes 1994, Hughes \& Tanner 2000). However, it is important to realise that this replenishment takes place against a background of benthic algal dominance (McCook 1999, Hughes et al. 2005, 2007, McCook et al. 2007) because disturbed coral reefs are almost universally colonised by some form of benthic algae (Diaz-Pulido \& McCook 2002, 2004) and degraded coral reefs are generally dominated by benthic algae (Table 1; Hughes et al. 1987, Done 1992, Hughes 1994, Connell et al. 1997, McCook 1999, Hughes et al. 2007). Indeed, the state of a reef as resilient or degraded is largely determined by whether algal dominance after disturbance is temporary, because coral populations recover, or becomes long term, precluding coral recruitment and regrowth. Impending climate change, with increasing sea temperatures and consequent increases in severity and frequency of mass coral bleaching (Hoegh-Guldberg 1999) and coral disease (Bruno et al. 2007), inevitably followed by coral mortality and subsequent algal overgrowth, will seriously reduce the capacity of coral populations to re-establish before subsequent disturbances (Hughes et al. 2003, 2007, Diaz-Pulido et al. 2007b).

Algal inhibition of coral replenishment has the potential to cause a serious bottleneck for reef recovery, depending on the nature of the algal assemblage. Diaz-Pulido \& McCook (2002) found algal colonisation, after the 1998 mass bleaching on the Great Barrier Reef, to be distinctly different on two reefs within $15 \mathrm{~km}$ of each other, with one reef dominated by fine, filamentous algal turfs, the other by larger, fleshy upright algae. Subsequent work at the first reef (Orpheus Island; Hughes et al. 2007) showed that the nature of the algal assemblage (turfs vs. larger seaweeds) had major effects on coral recruitment and on the resilience of the reef. Thus the effects of benthic algae on the processes of coral population recovery are critical to the resilience of coral reefs, and increasingly so with impending climate change.

Algal effects on coral recovery can be separated into competitive effects of algae on surviving coral colony fragments and effects on coral population replenishment, including reproduction (fecundity) and recruitment (including larval dispersal/supply, settlement and post-settlement survival and growth). Previous work has considered competitive effects in some detail and specifically identified algal effects on coral recruitment as a critical aspect and one for which there is little direct evidence (e.g., McCook et al. 2001a).

The present review focuses on effects of benthic alga on larval supply and recruitment, particularly on (1) habitat for coral replenishment, (2) production of coral larvae and their dispersal, (3) coral settlement and (4) post-settlement survival of corals. It is important to note that effects on different coral life-history stages are cumulative because corals must pass through every stage successfully to re-establish populations (Hughes \& Tanner 2000, Hughes et al. 2000). Given the considerable diversity of forms of algal assemblage (Table 1; Figure 1), the review emphasises the need to consider the effects of different forms of algae separately. Despite the importance of this topic, there are surprisingly few published studies (McCook et al. 2001a and see the section 'State of knowledge', p. 31). This review therefore has two aims: to review existing research and to provide a framework and context for future research.

\section{The diversity of algae and their effects on coral replenishment}

The benthic algae of coral reefs are extraordinarily diverse, ranging from small filaments a few millimetres high, through thick mats of tough algae, to large forests of leathery macrophytes (Figure 1; Steneck \& Dethier 1994, Walters et al. 2003). The nature of algal assemblages dominating degraded 
Table 1 Comparison of algal communities resulting on degraded reefs

\begin{tabular}{|c|c|c|c|}
\hline Case study & Disturbance(s) & $\begin{array}{l}\text { Dominant } \\
\text { macroalgal taxa }\end{array}$ & $\begin{array}{l}\text { Dominant macroalgal } \\
\text { functional group }\end{array}$ \\
\hline $\begin{array}{l}\text { Kaneohe Bay, } \\
\text { Hawaii }\end{array}$ & $\begin{array}{l}\text { Siltation (dredging \& land } \\
\text { clearing) and eutrophication } \\
\text { (sewage })^{1}\end{array}$ & $\begin{array}{l}\text { Dictyosphaeria } \\
\text { cavernosa (also } \\
\text { suspension- and } \\
\text { filter-feeding biota) }{ }^{2}\end{array}$ & Pulvinate or cushion-like \\
\hline \multirow[t]{2}{*}{$\begin{array}{l}\text { Discovery Bay, } \\
\text { Jamaica }\end{array}$} & $\begin{array}{l}\text { Hurricane Allen (1981) and } \\
\text { reduced herbivory } \\
\text { (overfishing) }^{3}\end{array}$ & $\begin{array}{l}\text { Turf algae (controlled } \\
\text { by grazing of } \\
\text { Diadema antillarum) }\end{array}$ & Filamentous/EAC \\
\hline & $\begin{array}{l}\text { Further reduction of herbivory: } \\
\text { mass mortality of Diadema } \\
\text { antillarum })^{5}\end{array}$ & $\begin{array}{l}\text { Dictyota, Padina, } \\
\text { Halimeda and } \\
\text { Lobophora }^{4}\end{array}$ & $\begin{array}{l}\text { Corticated foliose, articulated } \\
\text { calcareous }\end{array}$ \\
\hline $\begin{array}{l}\text { La Saline Reef, } \\
\text { Reunion }\end{array}$ & $\begin{array}{l}\text { Chronic nutrient pollution from } \\
\text { groundwater and overfishing } \\
\text { — mortality to corals from } \\
\text { algal overgrowth }{ }^{6}\end{array}$ & $\begin{array}{l}\text { Padina, Gracilaria } \\
\text { crassa }^{6}\end{array}$ & $\begin{array}{l}\text { Corticated foliose, corticated } \\
\text { macrophyte }\end{array}$ \\
\hline $\begin{array}{l}\text { Moorea, French } \\
\text { Polynesia }\end{array}$ & $\begin{array}{l}\text { Dredging for building material } \\
\text { (siltation) }{ }^{7} \text {, coastal develop- } \\
\text { ment (sedimentation and } \\
\text { sewage })^{8} \text {, agriculture (terres- } \\
\text { trial run-off), overfishing, } \\
\text { Acanthaster planci (1982) }{ }^{9,10} \\
\text { Silt-laden wet season run-off }{ }^{2}\end{array}$ & $\begin{array}{l}\text { Boodlea siamensis, } \\
\text { Sargassum sp. and } \\
\text { Turbinaria ornata }{ }^{11}\end{array}$ & $\begin{array}{l}\text { Filamentous (cushion-like), leathery } \\
\text { macrophyte }\end{array}$ \\
\hline $\begin{array}{l}\text { Malidi, Watamu, } \\
\text { Mombasa \& } \\
\text { Kisite Marine } \\
\text { National Parks, } \\
\text { Kenya (protected) }\end{array}$ & Mass bleaching $^{12}$ & Not reported & $\begin{array}{l}\text { Filamentous and diminutive algae, } \\
\text { fleshy algae; mass bleaching led to } \\
\text { an increase of turf algae by } 88 \% \\
(31 \% \pm 3.7 \% \text { to } 58.5 \% \pm 3.6 \% \text { mean } \\
\pm \text { SEM), increase of fleshy algae by } \\
115 \%(4.5 \% \pm 1.6 \% \text { mean } \pm \text { SEM to } \\
9.8 \% \pm 2.3 \% \text { mean } \pm \text { SEM })^{12}\end{array}$ \\
\hline $\begin{array}{l}\text { Vipingi, Kanamai, } \\
\text { Ras Iwatine \& } \\
\text { Diani reefs } \\
\text { (non-park, } \\
\text { unprotected) }\end{array}$ & Mass bleaching and overfishing ${ }^{12}$ & Not reported & $\begin{array}{l}\text { Filamentous and diminutive algae, } \\
\text { fleshy algae; mass bleaching led to } \\
\text { an increase of fleshy algae by } 222 \% \\
(4.0 \% \pm 31.2 \% \text { to } 12.9 \% \pm 4.3 \% \\
\text { mean } \pm \text { SEM) and no significant } \\
\text { change of turf algae after bleaching } \\
\text { disturbance }^{12}\end{array}$ \\
\hline $\begin{array}{l}\text { Glovers Reef, } \\
\text { Belize, Caribbean }\end{array}$ & $\begin{array}{l}\text { Disease \& reduction in herbivory } \\
\text { (by diseases and overfishing) }\end{array}$ & $\begin{array}{l}\text { Lobophora variegata, } \\
\text { Dictyota, Turbinaria, } \\
\text { Sargassum }\end{array}$ & $\begin{array}{l}\text { Corticated foliose, leathery } \\
\text { macrophyte }^{13}\end{array}$ \\
\hline $\begin{array}{l}\text { San Salvador, } \\
\text { Bahamas }\end{array}$ & Bleaching \& hurricanes & Not reported & $\begin{array}{l}\text { Algal turfs, macroalgae and } \\
\text { encrusting algae }^{14}\end{array}$ \\
\hline $\begin{array}{l}\text { Experimental } \\
\text { simulation of } \\
\text { overfishing }\end{array}$ & $\begin{array}{l}\text { Mass bleaching of corals, } \\
\text { experimental exclusion of large } \\
\text { fishes }\end{array}$ & $\begin{array}{l}\text { Sargassum spp. (also } \\
\text { Padina, Lobophora) }\end{array}$ & $\begin{array}{l}\text { Leathery macrophyte, corticated } \\
\text { foliose }^{15}\end{array}$ \\
\hline
\end{tabular}

Note: Macroalgal functional groups are based on those in Steneck \& Dethier's (1994) categorisation with pulvinate or cushion-like alga as an additional group (R.S. Steneck personal communication). Superscript numbers indicate references as follows: ${ }^{1}$ Smith et al. 1981, ${ }^{2}$ Done $1992,{ }^{3}$ Hughes $1994,{ }^{4}$ Hughes et al. 1987, ${ }^{5}$ Lessios $1988,{ }^{6}$ Cuet et al. 1988, ${ }^{7}$ Gabrie et al. 1985, ${ }^{8}$ Salvat $1987,{ }^{9}$ Bouchon $1985,{ }^{10}$ Faure 1989, ${ }^{11}$ Payri \& Naim 1982, ${ }^{12}$ McClanahan et al. 2001, ${ }^{13}$ McClanahan \& Muthiga 1998, ${ }^{14}$ Ostrander et al. 2000, ${ }^{15}$ Hughes et al. 2007 and L. McCook (personal observation). EAC, epilithic algal community, diminutive (less than a few $\mathrm{cm}$ high) algal forms growing on the reef substratum. 


\section{CHICO L. BIRRELL ET AL.}
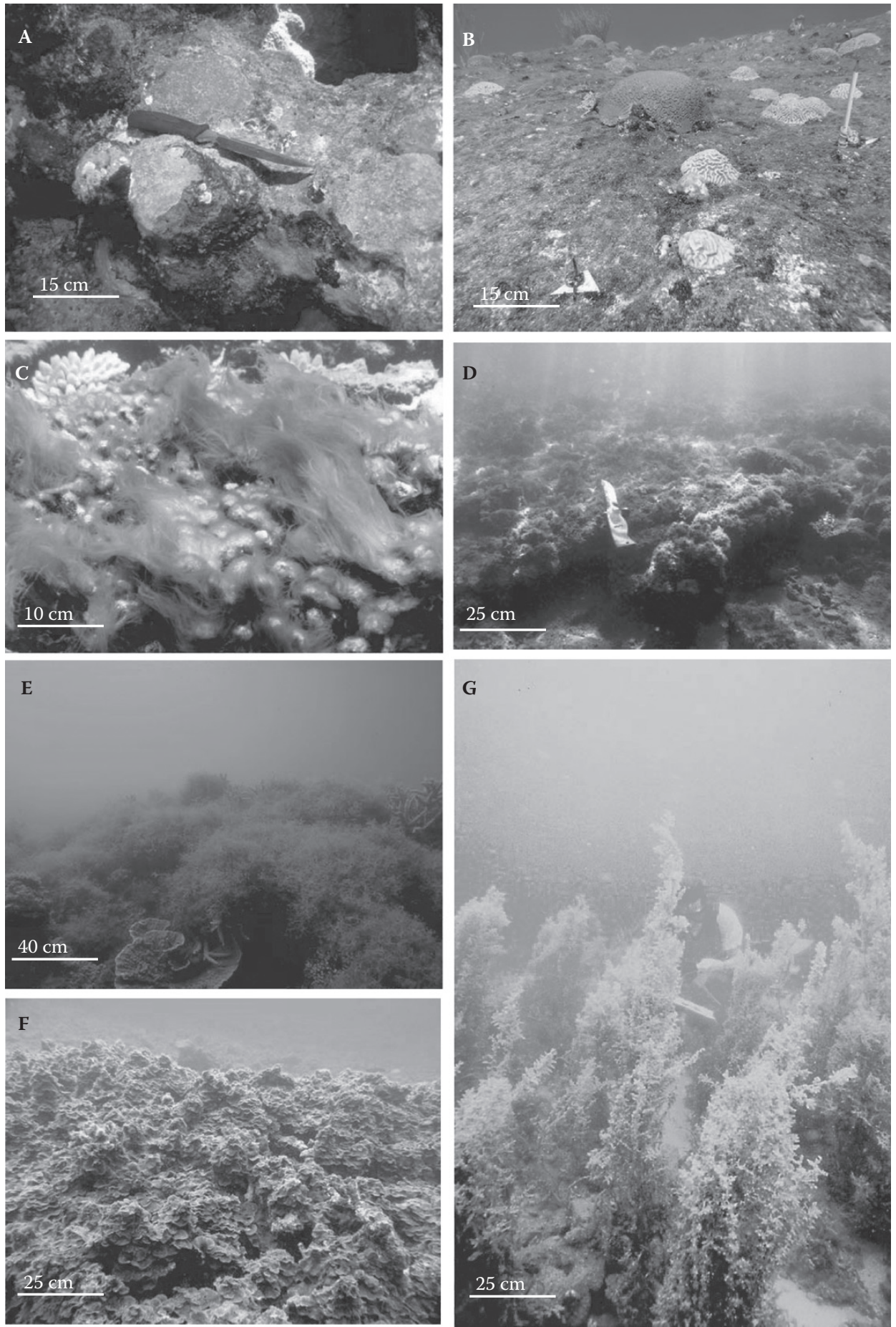

Figure 1 (See also Colour Figure 1 in the insert following p. 250.) Different algal assemblages dominating reef habitats, creating large differences in the suitability of the habitat for coral replenishment. A. Crustose calcareous algae, especially from the Order Corallinales, form a calcified crust over the substratum and are generally associated with habitats that promote coral recruitment.

(continued on facing page) 
reefs can differ enormously, depending on factors such as the extent and cause of degradation or propagule supply (Table 1 and references therein; Done 1992, McCook 1999). Clearly, such different forms and assemblages have very different characteristics (Littler et al. 1983, Olson \& Lubchenco 1990, Steneck \& Dethier 1994) and consequently vastly different effects on coral replenishment processes (Figures 1 and 2).

Addressing this diversity is a key challenge for understanding algal effects on reefs. With an estimated 600 species of algae on the Great Barrier Reef (Diaz-Pulido \& McCook in press), species-level treatment is not practical and higher taxonomic distinctions are not well correlated with ecological traits (e.g., a small area of filamentous turfs may include 30-50 species from a wide range of families and phyla). Algal characteristics most relevant to ecological processes are not the traits linked to taxonomic categories but include physical (e.g., height, structure, growth form) and chemical traits (e.g., production of allelopathic chemicals). Most of the relevant physical attributes are effectively captured in the commonly used 'functional groups' (Littler 1980, Littler \& Littler 1980, Littler et al. 1983, Carpenter 1990, Olson \& Lubchenco 1990, Steneck \& Dethier 1994), which have been previously used to summarise and simplify algal-coral interactions (McCook et al. 2001a). Chemical traits are more difficult to simplify because secondary metabolites are often species specific (e.g., Walters et al. 2003, Kuffner et al. 2006). The algal functional groups of Steneck \& Dethier (1994), listed in Table 2, are used primarily in this review, with reference to individual taxa where necessary.

\section{Coral replenishment processes, resilience and terminology}

Terminology in this review closely follows that defined by Harrison \& Wallace (1990). Coral replenishment makes combined reference to larval supply, settlement, and post-settlement processes. In the context of this review, effects of algae on larval supply include impacts on reproduction, fecundity and dispersal. Two reproductive modes are distinguished for corals: spawning refers to gamete release from parent coral polyps followed by external fertilisation and development; brooding refers to development of planulae larvae within the parent coral polyp, which are generally competent to settle soon after their release. Settlement involves the attachment of coral larvae to the substratum. Presettlement behaviour refers to intensive testing and searching behaviour and exploration of the substratum by larvae that generally precedes settlement. Often used synonymously with settlement, metamorphosis involves morphological changes such as differentiation of aboral epidermis in preparation for skeleton deposition, and consolidates settlement to form a spat. Settlement can reverse, with larvae detaching and returning to presettlement behaviour under unfavourable conditions (Sammarco 1982, Richmond 1985, Vermeij \& Bak 2002). In this review, settlement and

Figure 1 (continued) B. Filamentous algal turfs, closely cropped by herbivorous fishes and sea urchins, create a low turf (1-5 mm in height), which is compatible with coral recruitment. C. Aggregations of cyanobacteria (microalgae) may form longer filaments (30-100 $\mathrm{mm}$ in height) and often generate hostile chemical conditions. D. Thick mats of larger, more robust corticated algae may create a dense layer over much of the reef substratum (50-150 mm in height), trapping sediments and generating chemical and nutrient conditions that may be inimical to coral settlement and early recruits. E. A dense mat of the ephemeral, corticated brown alga, Chnoospora implexa, covering large areas of reef and live corals (up to $500 \mathrm{~mm}$ high). Because this mat was highly seasonal, and short-lived, it subsequently disappeared, with little apparent impact on the underlying corals. The impact of such a mat on coral replenishment would depend strongly on the timing of the bloom relative to coral spawning and settlement. F. Dense mat of the corticated, foliose brown alga, Lobophora variegata, covering corals killed during a mass bleaching event and rendering the substratum apparently inaccessible to coral recruits. G. Canopy of the leathery macrophyte, Sargassum (brown alga), which may reach heights of up to 3-4 m and densities of 100 plants $\mathrm{m}^{-2}$, pre-empting space for coral recruitment and significantly altering light and hydrodynamic regimes. 
Table 2 Summary of literature on coral recruitment, classified by phase of recruitment, and type of study, against algal functional groups, environmental and other ecological factors

\begin{tabular}{|c|c|c|c|c|c|}
\hline \multirow[b]{2}{*}{ Factors } & \multicolumn{3}{|c|}{ Recruitment phase } & \multicolumn{2}{|c|}{ Type of study } \\
\hline & $\begin{array}{c}\text { Larval } \\
\text { settlement }\end{array}$ & $\begin{array}{c}\text { Early } \\
\text { post-settlement } \\
(<0.5 \mathrm{~cm} \emptyset) \\
\text { survival }\end{array}$ & $\begin{array}{c}\text { Juvenile } \\
(1-5 \mathrm{~cm} \emptyset) \\
\text { coral survival }\end{array}$ & $\begin{array}{c}\text { Recruitment } \\
\text { on artificial } \\
\text { surface }\end{array}$ & $\begin{array}{c}\text { In situ } \\
\text { recruitment } \\
\text { (on benthos) }\end{array}$ \\
\hline \multicolumn{6}{|c|}{ Macroalgal functional groups } \\
\hline Crustose & $11^{1-6,36,53,58,59,63}$ & $2^{13,63}$ & & & \\
\hline Articulated calcareous & $3^{6,60,63}$ & $1^{63}$ & & & \\
\hline Microalgae & $2^{51,52}$ & & & & \\
\hline Filamentous & $3^{54,61,63}$ & $3^{14,57,63}$ & $2^{16,56}$ & & \\
\hline Foliose & $1^{61}$ & & & $1^{40}$ & \\
\hline Corticated foliose & $2^{52,53}$ & & $5^{9,29,55,62}$ & $1^{11 \mathrm{~T}}$ & $5^{9,11 \mathrm{~T}, 29,39}$ \\
\hline Corticated macrophytes & $3^{4,52,61}$ & & $4^{9,29,62}$ & $1^{11 \mathrm{~T}}$ & $5^{9,11 T, 29,39}$ \\
\hline Leathery macrophytes & $2^{61,63}$ & $1^{63}$ & $3^{9,29}$ & $2^{11 \mathrm{~T}, 28}$ & $5^{9,11 T, 29,39}$ \\
\hline \multicolumn{6}{|l|}{ Environmental factors } \\
\hline Sediment & $3^{17,24,35}$ & & $1^{16}$ & & \\
\hline Light & $2^{22,34}$ & & & & \\
\hline Pollutants & $3^{21,25,41}$ & & & & \\
\hline Depth & $1^{42}$ & $2^{19,42}$ & $1^{16}$ & $7^{23,44-49}$ & \\
\hline Disturbance & & & & & $3^{9,26,43}$ \\
\hline $\begin{array}{l}\text { Other/spatial variation } \\
\text { (Great Barrier Reef only) }\end{array}$ & & & & $11_{33,43,44,48,50}^{7,18,23,27,30,32}$ & \\
\hline \multicolumn{6}{|l|}{ Other ecological factors } \\
\hline Grazer damage & & $1^{12}$ & & $1^{15}$ & $1^{8}$ \\
\hline Damselfish territories & & & $1^{10}$ & $2^{13,28}$ & \\
\hline Allelopathy & $3^{20,37,38}$ & & & $2^{31}$ & \\
\hline
\end{tabular}

Note: Table entries give the number of studies found for each combination of topics; superscript numbers indicate the relevant references as follows: ${ }^{1}$ Morse et al. 1988, ${ }^{2}$ Morse \& Morse 1991, ${ }^{3}$ Morse et al. 1994, ${ }^{4}$ Morse et al. 1996, ${ }^{5}$ Raimondi \& Morse 2000, ${ }^{6}$ Heyward \& Negri 1999, ${ }^{7}$ Hughes et al. 1999, ${ }^{8}$ Sammarco 1980, ${ }^{9}$ Hughes 1985, 1989, 1996 (based on related data), ${ }^{10}$ Potts 1977, ${ }^{11}$ Miller \& Hay 1996, ${ }^{12}$ Rylaarsdam 1983, ${ }^{13}$ Sammarco \& Carleton 1981, ${ }^{14}$ Birkeland 1977, ${ }^{15}$ Brock 1979, ${ }^{16}$ Bak \& Engel 1979, ${ }^{17}$ Babcock \& Davies 1991, ${ }^{18}$ Babcock 1988, ${ }^{19}$ Mundy \& Babcock 2000, ${ }^{20}$ Fearon \& Cameron 1996, ${ }^{21}$ Reichelt-Brushett \& Harrison 2000, ${ }^{22}$ Kuffner 2001, ${ }^{23}$ Sammarco 1991, ${ }^{24}$ Hodgson 1990, ${ }^{25}$ Epstein et al. 2000, ${ }^{26}$ Mumby 1999, ${ }^{27}$ Hughes et al. 2000, ${ }^{28}$ Gleason 1996, ${ }^{29}$ Connell et al. 1997, 2004, ${ }^{30}$ Harriott \& Fisk 1988, ${ }^{31}$ Maida et al. 1995a,b, ${ }^{32}$ Fisk \& Harriott 1990, ${ }^{33}$ Sammarco \& Andrews 1989, ${ }^{34}$ Mundy \& Babcock 1998, ${ }^{35}$ Gilmour 1999, ${ }^{36}$ Negri et al. 2001, ${ }^{37}$ Fearon \& Cameron 1997, ${ }^{38}$ Koh \& Sweatman 2000, ${ }^{39}$ Tanner 1995, ${ }^{40}$ Fairfull \& Harriott 1999, ${ }^{41}$ Negri \& Heyward 2001, ${ }^{42}$ Babcock \& Mundy 1996, ${ }^{43}$ Dunstan \& Johnson 1998, ${ }^{44}$ Harriott 1985, ${ }^{45}$ Wallace \& Bull 1981, ${ }^{46}$ Wallace 1985a, ${ }^{47}$ Wallace 1985b, ${ }^{48}$ Banks \& Harriott 1996, ${ }^{49}$ Harriott 1992 , ${ }^{50}$ Baird \& Hughes 1997, ${ }^{51}$ Kuffner \& Paul 2004, ${ }^{52}$ Kuffner et al. 2006, ${ }^{53}$ Baird \& Morse 2004, ${ }^{54}$ Birrell et al. 2005, ${ }^{55}$ Edmunds \& Carpenter 2001, ${ }^{56}$ Van Moorsel 1985, ${ }^{57}$ Miller \& Barimo 2001, ${ }^{58}$ Kitamura et al. 2007, ${ }^{59}$ Harrington et al. 2004, ${ }^{60}$ Nugues \& Szmant 2006, ${ }^{61}$ Vermeij et al. in review, ${ }^{62}$ Box \& Mumby 2007, ${ }^{63}$ Maypa \& Raymundo 2004. Superscript $\mathrm{T}$ indicates temperate latitude zone study. Note that studies of recruitment on artificial substrata (e.g., ceramic settlement plates) may be confounded by the material of the substrata, and in situ studies may miss many small and cryptic recruits. Both approaches may confound differences in settlement with post-settlement mortality. Literature survey post-1978; for environmental and other ecological factors survey is not comprehensive because recent publications number in the hundreds: survey illustrates proportional research effort; some studies are reported in more than one reference. 
metamorphosis are treated together. Post-settlement survival refers to the levels of survival and mortality after settlement (e.g., due to environmental disturbance, competition with other organisms) and may vary strongly with size or age of the coral. Post-settlement survival is generally used more specifically to refer to the dynamics of corals not visible in situ with the naked eye (i.e., $<0.5 \mathrm{~cm}$ in diameter or approximately 6 months after settlement; e.g., Wilson \& Harrison 2005), whereas recruit survival generally refers to the dynamics of corals visible in situ (generally with diameters $>0.5 \mathrm{~cm}$ and more than 6 months after settlement; e.g., Hughes et al. 2007). In the literature, data on coral recruitment often refer to identification of corals when visible in the field, photographs or on retrieved surfaces (i.e., diameter greater than $\sim 0.5 \mathrm{~cm}$; Wallace $1985 \mathrm{~b}$ ), with limited capacity to distinguish the dynamics of settlement and those of post-settlement growth and survival. Thus effects reported on recruitment may arise from the effects on either the settlement or post-settlement stage.

\section{State of knowledge}

The effects of benthic algae on coral replenishment are inadequately studied given their importance to reef ecology and persistence. There are relatively few published studies that directly address these effects and those few address only a fraction of benthic algal species and provide very uneven coverage of different algal types, environmental influences or coral life stages (Table 2). This makes it very difficult to detect and describe even preliminary patterns (Table 3).

Although it is widely accepted that benthic algae have predominantly negative effects on coral recruitment during reef disturbance and degradation (e.g., McCook et al. 2001a, Mumby et al. 2007), research to date has focused strongly on the induction of coral settlement by crustose calcareous algae (CCA*) in the Order Corallinales (Tables 2, 3 and 4), with relatively few detailed studies of coral settlement using the algae commonly present during reef degradation. In contrast, most research into algal effects on post-settlement survival and growth has focused on large, fleshy algae, with turfing and crustose forms under-represented. Importantly, much of the evidence for algal inhibition of coral recruitment stems largely from field surveys of Caribbean reefs using visual or photographic methods that only detect recruits at approximately 6 months post-settlement $(>\sim 0.5 \mathrm{~cm}$; e.g., Hughes 1989, 1996, Edmunds \& Carpenter 2001, Edmunds 2002), preventing distinctions between effects on settlement and post-settlement survival (see Harrison \& Wallace 1990; similar limitations apply even to studies using microscopic examination of artificial substrata if post-settlement mortality is not monitored). There is even less direct information available on the effects of algal assemblages on 'supply-side' processes of fecundity and larval dispersal and survival.

Another knowledge gap involves interactions and synergies between algal effects and other stressors on coral replenishment (but see Birrell et al. 2005). Finally, the tendency for under-reporting of 'negative' results, showing no effect for a particular factor (Underwood 1999), means that reviews such as this may under-represent aspects where good research methods have shown the lack of effects. Overall, there is a need for significant further research into algal effects on coral replenishment, using a broader range of algal types, distinguishing between effects on different coral stages and exploring the different mechanisms for those effects.

Given the paucity of direct evidence for algal effects on coral replenishment, the review begins with a summary of evidence for effects of algae on physical and chemical aspects of habitat condition and considers how that evidence may be relevant to coral replenishment. The effects of environmental conditions and pressures on coral replenishment have been reviewed elsewhere (e.g., Harrison \& Wallace 1990, see also Table 2).

\footnotetext{
* Note that throughout this review, CCA is used to include all crustose, calcareous algae, including those in the Order Corallinales, but also taxa such as Peyssonnelia, from other taxonomic groups; 'coralline' is used to specify taxa from the Order Corallinales.
} 


\section{CHICO L. BIRRELL ET AL.}
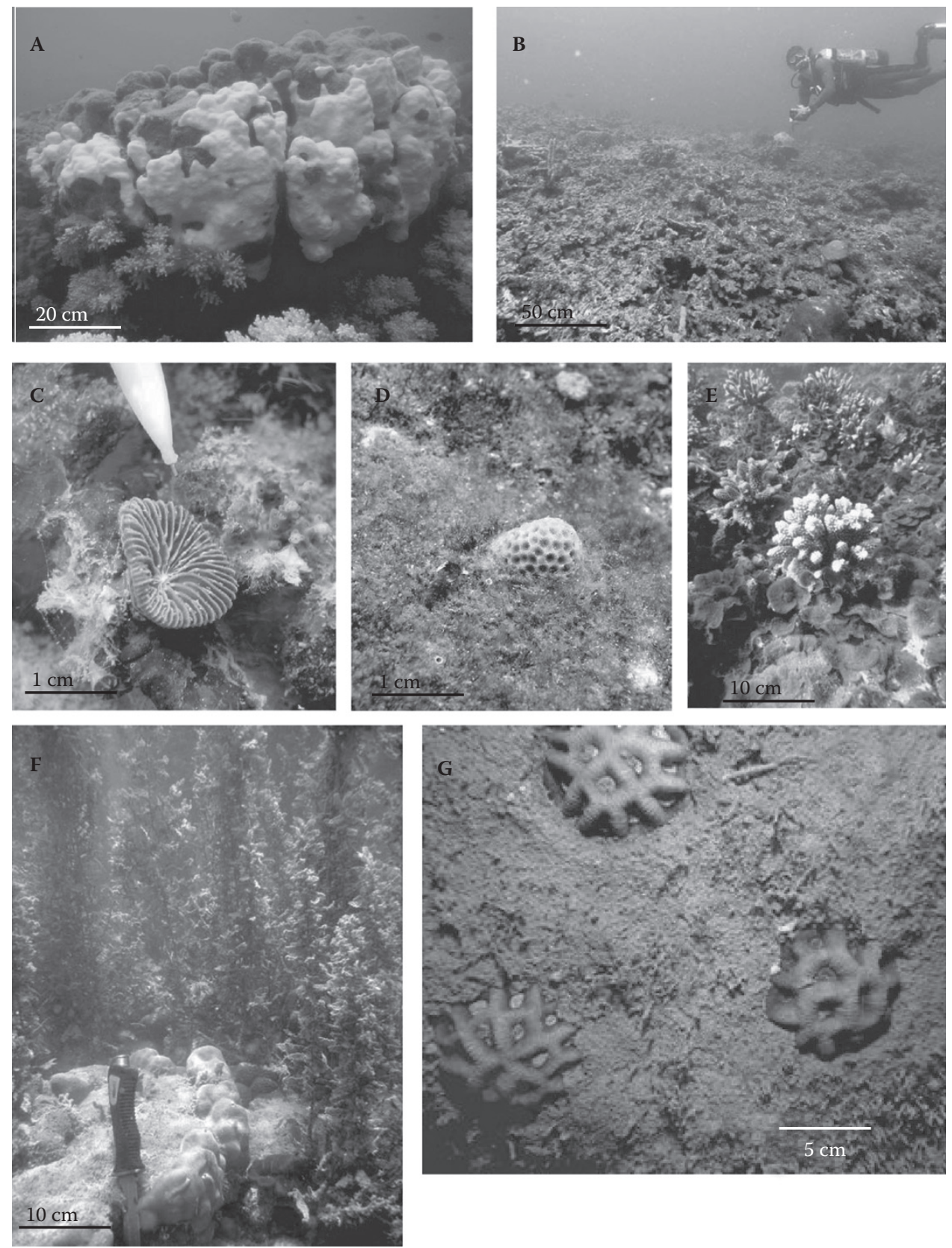

Figure 2 (See also Colour Figure 2 in the insert.) Disturbance, algal colonisation and effects of algae on coral recruitment. A. Colonisation of severely bleached coral tissue by fine filamentous algae. Disturbances that lead to coral tissue death usually result in colonisation of exposed coral skeleton by some form of benthic algae. Subsequent succession may result in very different algal assemblages, with very different consequences for coral replenishment. B. Overgrowth of damaged corals by the corticated, foliose brown alga, Lobophora variegata, has dramatically reduced substratum available for coral settlement. C. Healthy coral recruit attached to a crustose calcareous alga; such algae may enhance settlement of coral larvae. D. Coral recruit emerging from filamentous algal turf. During settlement and early growth, the smaller coral would have been more strongly affected by physical and chemical conditions in the turf. (continued on facing page) 


\section{Effects of macroalgae on habitat conditions for coral replenishment}

Just as trees are critical to the nature of a forest habitat, macroalgae may have major effects on the physical and chemical conditions of the reef environment, which may in turn affect the larval dispersal, settlement and survival of corals (Harrison \& Wallace 1990). Although there is a significant amount of information on such habitat effects (e.g., Amsler et al. 1992, Martin-Smith 1993), especially from temperate algal beds (e.g., Reed \& Foster 1984, Wing et al. 1993, Valiela et al. 1997, Eckman et al. 2003) the focus here is on key aspects relevant to coral replenishment, that is, benthic space, light availability, water flow and turbulence, benthic sediment regimes and chemical environments, including nutrient regimes and microbial environments.

\section{Effects of macroalgae on benthic space}

The availability of benthic space, for coral settlement and growth, is strongly limited by algal assemblages, which occupy much of the substratum on coral reefs. Benthic algae are rapid colonists of newly available bare space on coral reefs, commencing with diatoms, microbes and cyanobacteria, then simple filamentous algae and CCA, followed by more complex filamentous turfs and perhaps by larger, more robust algal types (McClanahan 2000, McClanahan et al. 2001, Diaz-Pulido \& McCook 2002, Diaz-Pulido et al. 2007a). Most of the apparent 'bare space' on reefs is in fact occupied by variable mixtures of CCA and very short, closely grazed filamentous algal turfs, barely apparent to the naked eye.

The extent to which this space is unavailable to corals will depend strongly on the nature and density of the algal assemblage; a sparse, close-cropped turf-CCA assemblage will have very different impacts than a dense algal mat, or a bed of large, canopy-forming Sargassum seaweeds. Most algal assemblages probably do not completely preclude access to substratum for coral larvae, given their small size (500-2000 $\mu \mathrm{m}$ in diameter; Harrison \& Wallace 1990) relative to the spacing between algal filaments or the holdfast attachments of larger algae (authors' personal observation). However, dense algal assemblages will certainly hinder access to the substratum. It has been suggested that dense stands of filamentous algae prevent spores of other macroalgae reaching the substratum (Hruby \& Norton 1979, Olson \& Lubchenco 1990). In considering space occupied by algae, it is important to recognise that many algal assemblages form a distinct canopy, whether at the scale of tens of millimetres for algal turfs or metres for a Sargassum bed. Space under the canopy may be relatively bare or occupied by understorey species; on the inshore Great Barrier Reef, beds of the leathery macrophyte Sargassum often have substantial understorey cover of corals, smaller foliose macroalgae (e.g., Padina sp.) and filamentous turfs (authors' personal observation; see also McCook 1999, Hughes et al. 1987, 2007).

Furthermore, not all algal types will preclude coral settlement. Corals can settle and even grow on several types of macroalgae, primarily calcareous red macroalgae (Morse et al. 1994, Morse et al. 1996, Heyward \& Negri 1999, Raimondi \& Morse 2000, Harrington et al. 2004), but also filamentous (C. Birrell personal observation) and articulated calcareous green algae (Halimeda spp.; Nugues \& Szmant 2006). However, most filamentous and fleshy algae will not provide suitable attachment sites for coral colony formation and many taxa have antifouling mechanisms such as shedding of surface cell layers (Olson \& Lubchenco 1990, de Nys \& Steinberg 1999).

Figure 2 (continued) E. Acropora corals emergent from a dense mat of Lobophora variegata (as in B and Figure 1F). F. Leathery macrophytes (e.g., Sargassum) may form an extensive canopy, but still retain significant understorey substratum suitable for coral settlement and recruitment, such as the filamentous turfs shown here. G. Trapping of sediments by filamentous algal turfs may enhance stress experienced by coral recruits and significantly reduce the suitability of habitat for their survival and growth. 
CHICO L. BIRRELL ET AL.

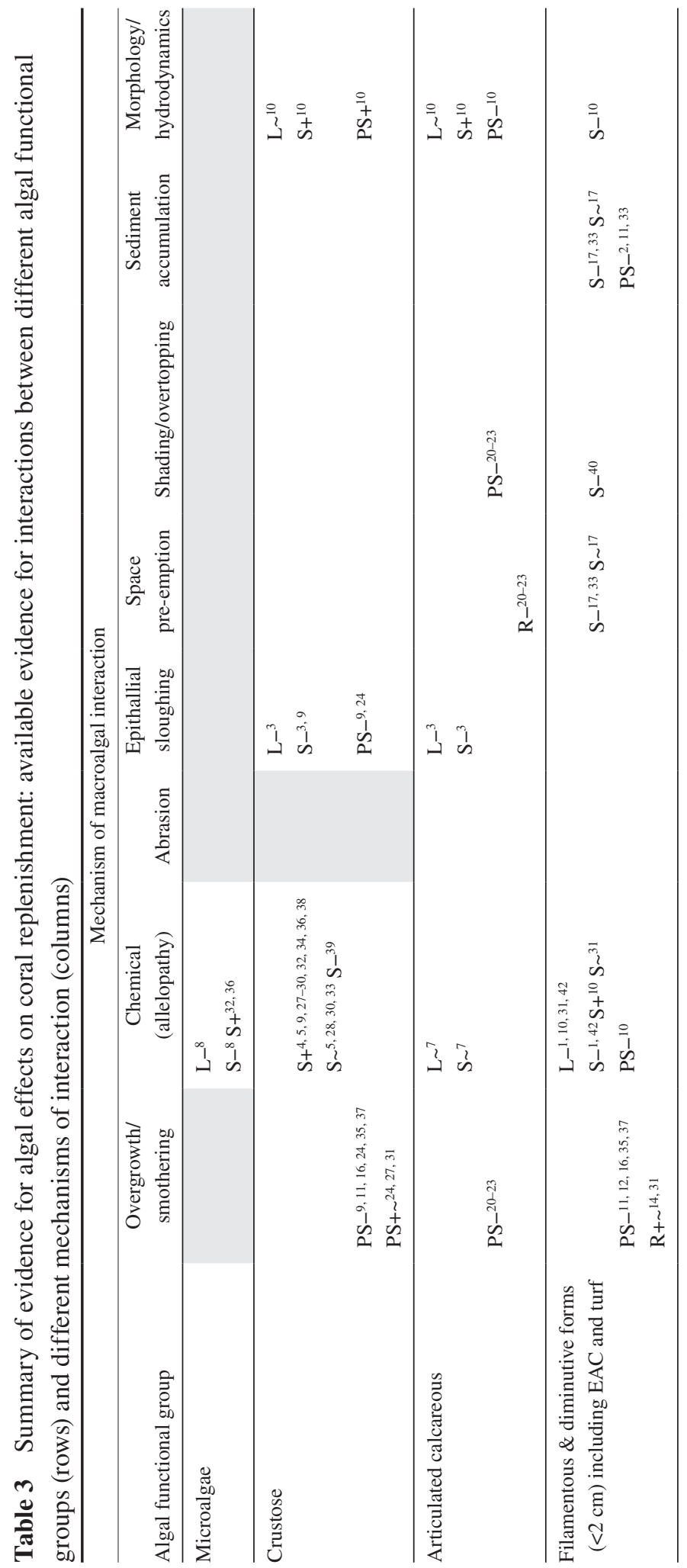




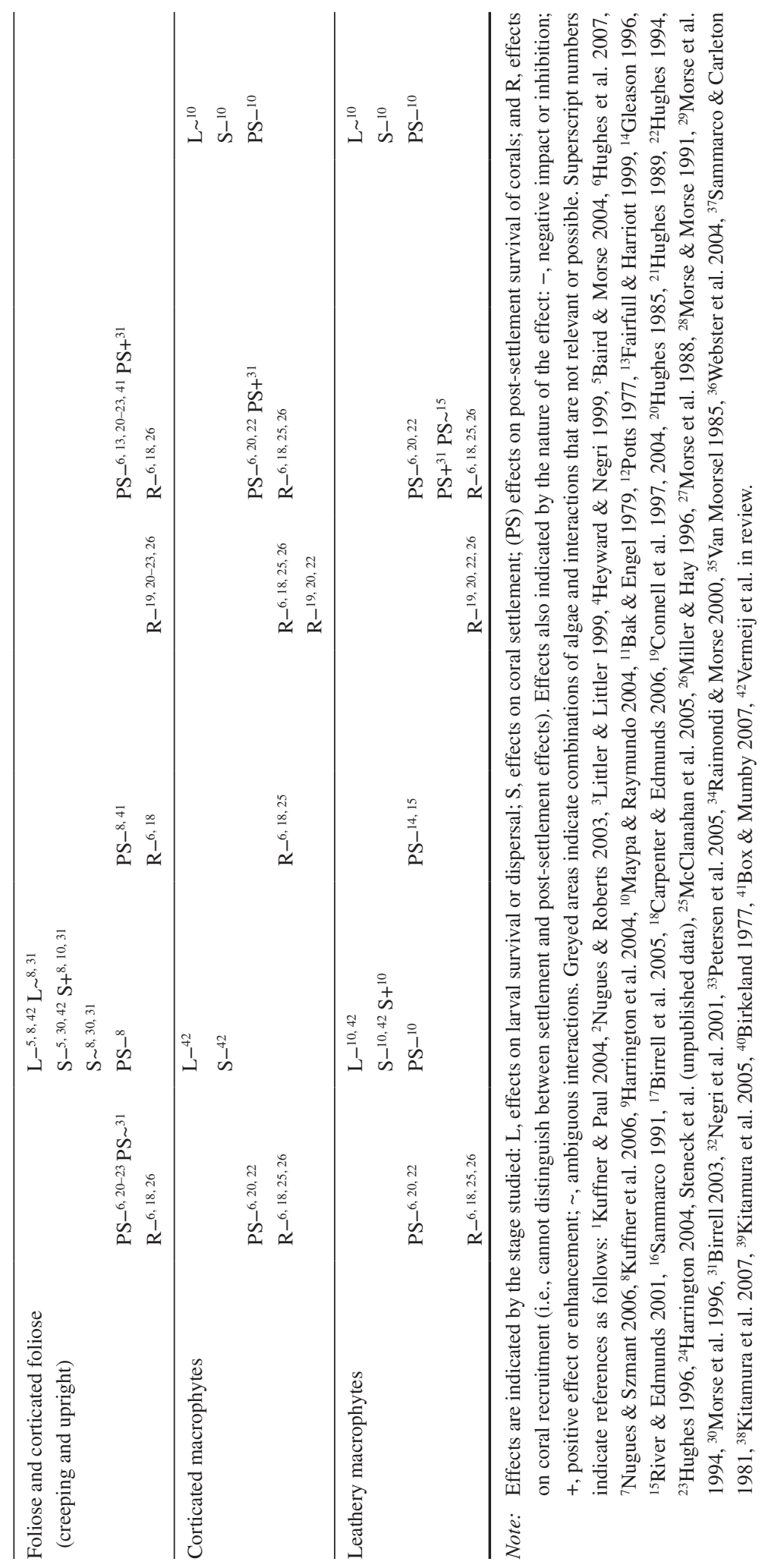


CHICO L. BIRRELL ET AL.

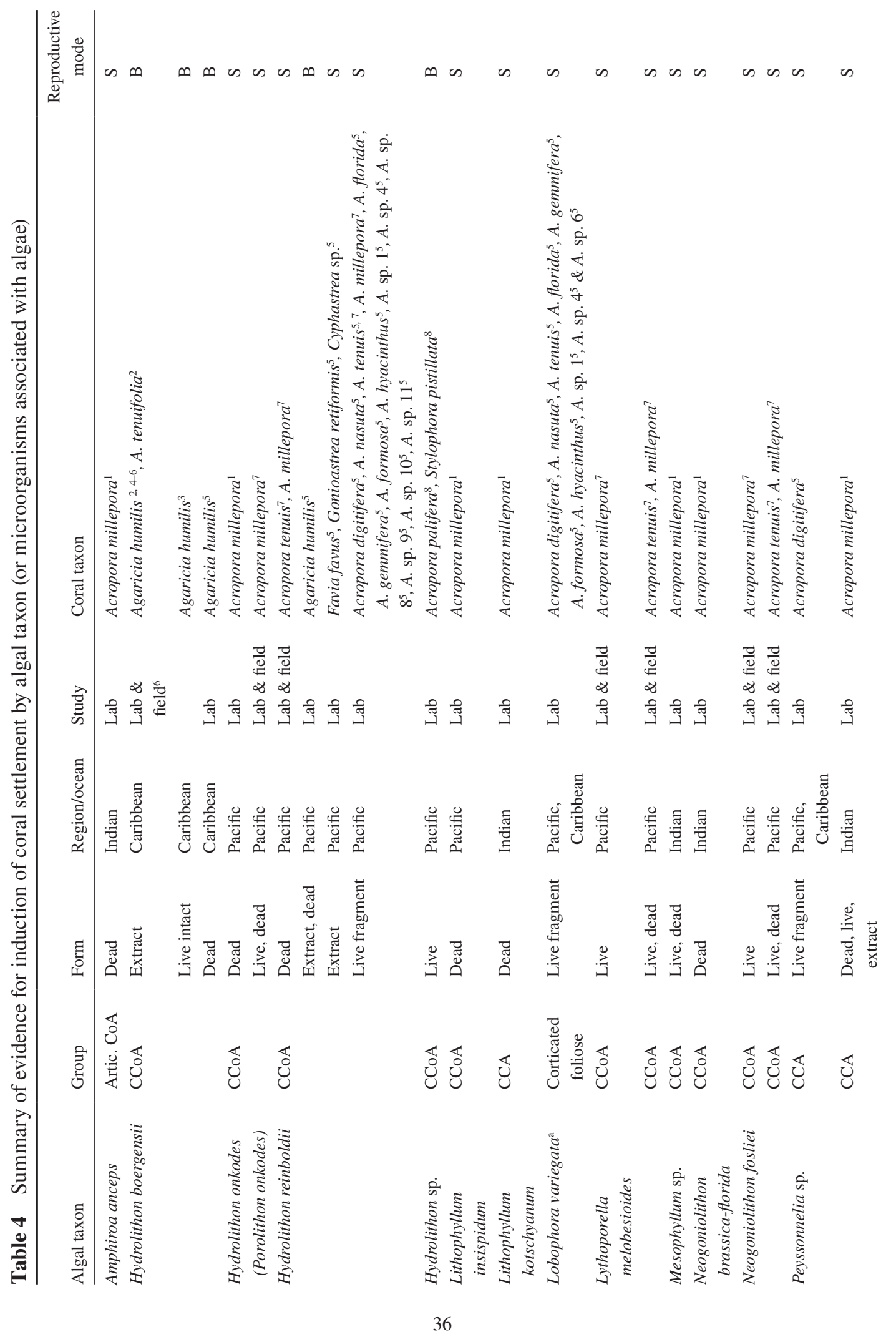




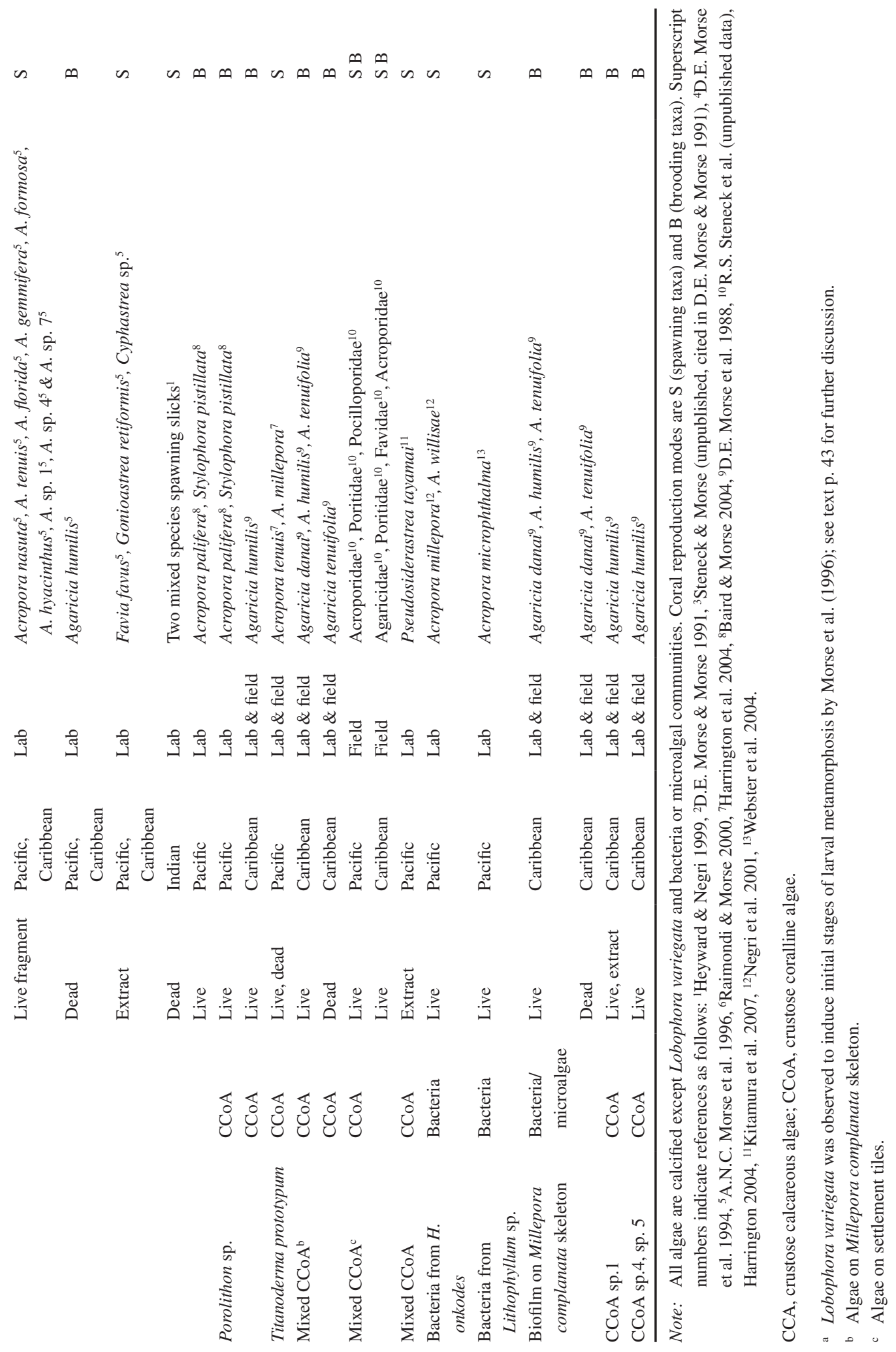




\section{Impacts of macroalgae on light conditions}

Most macroalgae create shade on spatial scales relevant to coral larvae and recruits and so may affect photosynthesis, as well as factors such as ultraviolet radiation stress, calcification, localised temperatures and visibility of corals to predators. Although there is little direct evidence relevant to coral reefs, recent results (Box \& Mumby 2007) have shown strongly detrimental effects of shading by the brown foliose algae Lobophora variegata and Dictyota pulchella. The extent and nature of shading will vary considerably between algal functional groups and will depend more on the nature and density of the entire algal assemblage than individual algae (Reed \& Foster 1984, Wing et al. 1993, River \& Edmunds 2001, Quan-Young \& Espinoza-Avalos 2006). Upright algae such as leathery macrophytes (e.g., Sargassum) and algae with foliose morphologies (e.g., Padina, Ulva) can individually shade substratum at scales of square centimetres to square metres, yet assemblage canopies may shade entire reef zones, especially in the case of algal phase shifts (Hughes et al. 1987, authors' personal observation). Filamentous algae, articulated calcareous algae (e.g., Amphiroa) and corticated macrophytes (e.g., Hypnea, Dictyota) are likely to create smaller and less-continuous areas of shade $\left(10^{-2}\right.$ to $\left.10^{1} \mathrm{~cm}^{2}\right)$. Smaller algal assemblages will generally have less tissue to absorb light, and hence create less shade, although this will depend on the density of the algal assemblages. For example, articulated calcareous algae (Halimeda) can form dense enough stands to strongly block out light (Hay 1981).

Importantly, shading by algal canopies will affect the spectral quality of light transmitted and reflected, absorbing most strongly in the photosynthetic wavelengths, with consequences for coral photosynthesis. Both light intensity and spectral quality are cues for habitat selection during settlement of corals (Mundy \& Babcock 1998), so that these impacts may also affect larval presettlement behaviour and settlement preferences.

Furthermore, shading by algae may not be exclusively detrimental. Although light is important for coral photosynthesis and calcification (Barnes \& Chalker 1990), strong light levels can have energetic costs, due to photoinhibition (Hoogenboom et al. 2006), and in extreme circumstances may overload the photosynthetic system, causing coral bleaching (Lesser 1997). Thus high light environments may favour development of coral colonies with self-shading morphologies (Oliver et al. 1983, Titlyanov 1991, Muko et al. 2000, Anthony et al. 2005), and, in some circumstances, shading by algae during mass bleaching has been shown to increase survival in mature (Jompa \& McCook 1998) and juvenile corals (up to 130 days old; Birrell 2003). However, it should be noted that these benefits are probably outweighed by other, negative impacts in the long term.

\section{Impacts of macroalgae on water flow and turbulence}

Different algal assemblages may have major effects on water flow speeds, gradients and turbulence, with potentially important consequences for coral replenishment. Water flow, gradients and turbulence affect the physical dispersal and settlement ability of larvae (reviewed by Abelson \& Denny 1997), and the development and survival of settled individuals, through effects on exchange of nutrients and other chemicals, important to rates of photosynthesis and respiration (Barnes \& Chalker 1990, Kuhl et al. 1995), and to the intensity of algal chemical interactions (e.g., allelopathy). Nutrient and carbon exchange may have significant impacts on rates of photosynthesis and respiration, in turn affecting coral energy budgets, potentially critical to the survival of juvenile corals. Water flow patterns are also critical to sediment deposition or abrasion (see next section) and other physical interactions (e.g., whiplash by algal fronds; Anthony \& Svane 1994, Vogel 1994, River \& Edmunds 2001).

The scale of algal impacts on flow dynamics is largely determined by the height and structure of the algal assemblage and so can be expected to differ markedly between algal functional 
groups. Kelp forests can influence coastal water circulation patterns (Jackson \& Winnant 1983) and leathery macrophytes such as Sargassum spp. can influence water flow within metres to decimetres of the substratum (Duggins et al. 1990; Sargassum beds, which may reach $3 \mathrm{~m}$ tall, are common on coastal coral reefs and may develop during algal phase shifts; e.g., McCook 1996, Hughes et al. 2007). Filamentous algae affect water flow within microns to millimetres of the substratum (Carpenter \& Williams 1993, Larkum et al. 2003). Indeed Carpenter \& Williams (1993) demonstrated filamentous turfs $4.0-6.0 \mathrm{~mm}$ in height can have major effects on boundary layer formation, reducing flow speeds up to 15 -fold within $3.0 \mathrm{~mm}$ of the surface of settlement tiles relative to above free-stream flow speeds.

Algal impacts on water flow are also strongly influenced by algal morphology and texture (e.g., Abelson \& Denny 1997), so that even crustose algae can significantly affect boundary layer water flow and turbulence. By enhancing the small-scale complexity of the surface, crustose algae generate variable-flow regimes in pressure points, eddies and sheltered pockets (Carpenter \& Williams 1993, Vogel 1994, Abelson \& Denny 1997). Vogel (1994) discusses algal adaptations to flow regimes and how roughness of surface features affects drag created in water. Put simply, morphologies with greater drag (i.e., less streamlined) have larger effects on flow regimes. It is also worth noting that epiphyte loading in algal canopies increases drag, generating greater downstream turbulence (Vogel 1994) although greater flow speeds can dislodge epiphyte communities (e.g., Bergey et al. 1995).

These effects on water flow occur at scales relevant to coral settlement and recruitment. The height of coral recruits ranges from microns at settlement, to centimetres after the first few years growth, so that they will be influenced by the effects on boundary layer dynamics and water flow gradients of even very short algae (e.g., filamentous turfs; Larkum et al. 2003).

\section{Impacts of macroalgae on benthic sediment regimes}

The effects of benthic algae on water flow may also affect sediment transport, and hence scouring and abrasion, and sediment deposition and resuspension (discussed above; see also Abelson \& Denny 1997). Benthic algae may also trap sediments, enhancing sediment deposition, and may influence sediment composition and chemistry, with potential impacts on coral life stages ranging from gamete fertilisation (Gilmour 1999) and larval settlement (Babcock \& Davies 1991, Birrell et al. 2005) to coral growth and survival (Rogers 1990, Riegl \& Branch 1995, Fabricius et al. 2003, Nugues \& Roberts 2003, Fabricius 2005).

Generally, increased turbulence and flow speed promote transport and resuspension of sediments (Abelson \& Denny 1997). This reduced turbulence and flow may reduce resuspension between algal holdfasts (Steneck 1997). This from algal surfaces (Stamski \& Field 2006), trapping sediments and enhancing deposition, with consequent impacts on coral replenishment. Purcell (2000) observed that sediment load in filamentous turf and diminutive algal assemblages increased with assemblage height across reef zones. Indeed, the relationship was approximately linear for all zones (reef base, fore-reef flat and midreef flat) except the reef crest, where Purcell (2000) suggested that higher wave energy disproportionately limited sediment accumulation (algal heights $<0.2 \mathrm{~cm}$ as opposed to $0.7-0.8 \mathrm{~cm}$ in other zones). Note, however, that potential feedback interactions are possible. In more turbulent areas such as reef crests, wave action may limit the height and density of algal assemblages, further limiting sediment trapping and accumulation (Cheroske et al. 2000, Becerro et al. 2006).

In contrast, in less-turbulent areas, sediment trapping by filamentous turfs may serve to anchor the assemblage, facilitating its growth and promoting algal overgrowth of corals or other organisms. This may even overwhelm defensive processes such as sloughing of coral mucus (McCook 2001, Nugues \& Roberts 2003) or epithallial cell layers of crustose coralline algae (Steneck 1997). 
Nonetheless, Purcell (2000) observed sediment loads to be least on substrata with relatively high coverage of crustose algae, apparently as a result of their limited potential to trap sediments compared with filamentous turfs.

Potential indirect effects of algae on the composition of trapped sediments may arise from ecological interactions between algae and other organisms such as herbivores. Different grazers favour different algal assemblages (e.g., Chittaro 2004 for parrotfishes), and grazing patterns can affect sediment composition through accumulation of faecal material. For example, Petersen et al. (2005) report the accumulation of faeces from grazing hermit crabs in sediments amidst algal turfs, and grazing and defaecation by parrotfishes can produce large amounts of carbonate sediments (Bellwood \& Choat 1990, Bellwood 1996).

Finally, algal impacts on sediment regimes may have more complex effects if the trapped sediments bind with chemicals such as nutrients, pesticides or other toxicants, increasing their retention. These pollutants generally have detrimental impacts on coral survival and replenishment (Epstein et al. 2000, Reichelt-Brushett \& Harrison 2000, Negri \& Heyward 2001, Furnas 2003, Negri et al. 2005, Markey et al. 2007) and sediment derived from terrestrial run-off from agriculture often contains high levels of such pollutants (Haynes \& Michalek-Wagner 2000, Ramade \& Roche 2006).

\section{Impacts of macroalgae on chemical environments, including nutrient regimes}

Macroalgal assemblages can have major effects on habitat chemistry and nutrient regimes, including effects on waterborne chemicals and nutrients; effects on particulate sediments, either suspended or as deposits; and effects on the surface area for settlement (e.g., due to surface chemistry of crustose algae; Amsler et al. 1992, Larkum et al. 2003, Walters et al. 2003). Many of these effects will influence fitness or fecundity of adult corals, or dispersal, survival or settlement and post-settlement survival and growth of coral larvae. Algal effects on chemical environments may derive directly from the biological properties of the algae, or from their effects on water flow, mixing and diffusion gradients, and sediment accumulation. During photosynthesis and respiration, macroalgae use or produce carbon dioxide and oxygen alternately, simultaneously fixing nitrogen (for cyanobacteria only), phosphorous and carbon, thereby generating localised gradients in oxygenation and nutrient concentrations that radiate from individual algae and assemblages (reviewed in Carpenter et al. 1991, Amsler et al. 1992, Larkum et al. 2003). Furthermore, algal alterations of environmental chemistry (alkalinity-acidity ratios) may affect coral calcification, and non-calcareous algae can even stimulate calcification in nearby corals enhancing their growth (McConnaughey et al. 2000). The nature and importance of these effects may be significantly altered by ocean acidification due to climate change (Diaz-Pullido, McCook et al. 2007).

\section{Impacts of macroalgae on microbial environments}

An emerging area of research involves interactions between macroalgae and microbial environments for corals. A series of studies have shown detrimental microbial colonisation of live corals to be enhanced by macroalgae (Nugues et al. 2004), apparently due to release of organic carbon by benthic algae (Kline et al. 2006, Smith et al. 2006). Recent work has found complex interactions between macroalgal and microbial effects on coral larval survival and settlement (Vermeij et al. in review). A number of studies have suggested coral settlement to be induced by microbial biofilms associated with coralline algae (Heyward \& Negri 1999, Negri et al. 2001, Webster et al. 2004). The emerging evidence for links between macroalgae and microbial assemblages suggests these effects are of considerable ecological significance, but current results are extremely limited, precluding identification of general patterns. 


\section{Effects of macroalgae on coral fecundity, larval dispersal and survival}

Reproduction and successful dispersal of coral propagules are crucial aspects of coral replenishment and hence reef resilience (e.g., Karlson 1999, Hughes et al. 2000, 2005, Hughes \& Tanner 2000, Knowlton \& Jackson 2001). A wide range of environmental stresses (e.g., turbidity, sediment, reduced light at depth, lesions, bleaching) has been shown to reduce coral reproductive output (e.g., Michalek-Wagner \& Willis 2001; review by Harrison \& Wallace 1990). Thus, stress or compromised energy budgets resulting from algal interactions (reviewed in McCook et al. 2001b) or algal alterations of the habitat (see 'Effects of macroalgae on habitat conditions', p. 33) are likely to reduce coral reproductive output but there is even less published evidence on these aspects than for effects on settlement or recruitment. Two studies have demonstrated effects of shading and abrasion (and potentially chemical effects) on coral reproductive output. Experimental clearance of algal assemblages (dominated by Halimeda spp., Chlorodesmis fastigiata, Peyssonnelia spp. and Turbinaria ornata) demonstrated that the algae caused a 50\% reduction in release of planulae from the brooding coral Acropora palifera (Tanner 1995). Hughes et al. (2007) observed algal reduction of coral fitness (measured as tissue thickness) and reproductive output (egg size, number of eggs per polyp, number of reproductive polyps per square centimetre) in fragments of the spawning coral Montipora digitata experimentally transplanted close to the large algae Sargassum spp. and Padina spp. (in contrast to transplants more distant from the large algae, but still close to filamentous turf algae).

Also relevant is recent work highlighting the potential for proximity to algae to increase coral disease. Release of organic carbon from benthic algae has been shown to alter microbial colonisation of live coral tissue (Kline et al. 2006, Smith et al. 2006), in some cases causing coral mortality. In another study, contact with the calcified, upright green alga Halimeda opuntia caused infection of the coral Montastraea faveolata by 'whiteplague type II' disease (Nugues et al. 2004).

Algal effects on fecundity can be expected to vary considerably among coral and algal taxa. For example, coral taxa vary in capacity to compensate for effects of stress on reproductive output (e.g., Cox 2007), algal impacts on mature corals vary considerably (McCook et al. 2001a) and reproductive output varies amongst corals (Hall \& Hughes 1996).

The fertilisation and survival of reproductive propagules may be affected directly by algal release of waterborne chemicals or by indirect environmental effects. Many reef macroalgae have been shown to release waterborne chemicals (including allelopathic secondary metabolites; Walters et al. 2003, Gross 2003) and such chemicals have been shown to be deleterious, even lethal, to a range of invertebrate larvae (Walters et al. 1996, reviewed by de Nys \& Steinberg 1999, Gross 2003) but there are only a few reports specific to corals. Waterborne chemicals from Sargassum polycystum and Laurencia papillosa killed unsettled larvae of Pocillopora damicornis over $24 \mathrm{~h}$ (Maypa \& Raymundo 2004). Chemicals released by the cyanobacterium Lyngbya majuscula also killed larvae of Acropora surculosa and Pocillopora damicornis (Kuffner \& Paul 2004). Extracts from some CCA showed toxic activity against coral larvae (Kitamura et al. 2005). Significantly, recent results have found macroalgae to have serious, indirect detrimental effects on coral larval survival, apparently due to enhancement of microbial densities in the water (Vermeij et al. in review).

Indirect effects on fertilisation by effects of algae on habitat conditions have not been specifically demonstrated but many of the effects discussed in the previous section have been shown to reduce fertilisation success of coral gametes. Examples include the effects of sediment regimes (Gilmour 1999), light and ultraviolet radiation levels (Edmunds et al. 2001), nitrogen and phosphorus levels (Harrison \& Ward 2001) and exposure to toxicants such as insecticides, fungicides (Markey et al. 2007), antifoulants (Negri et al. 2001) and herbicides (Negri et al. 2005). 
Larval dispersal is dependent on water movement and circulation patterns (Oliver \& Willis 1987, Willis \& Oliver 1990, Abelson \& Denny 1997, Storlazzi et al. 2006). Water movements may affect gamete dilution and fertilisation success (e.g., Oliver \& Babcock 1992), delivery or retention of larvae on a reef and larval vulnerability to benthic (Lindquist 1996, Fabricius \& Metzner 2004) and near-reef predators (Baird et al. 2001, Pratchett et al. 2001). Although there is currently no evidence to suggest the specific nature or importance of these indirect effects, it may be that effects of algal canopies on larval delivery at small scales explain the pattern of reduced coral settlement under Sargassum canopies (Jompa 2001).

\section{Effects of macroalgae on the settlement of coral larvae}

There is more published research available on algal effects on coral settlement than on the supply-side or post-settlement stages. Recent work has expanded the geographic scope of such studies, including work from the Caribbean (Kuffner et al. 2006, Nugues \& Szmant 2006), Hawaii (Vermeij et al. in review), Guam (Kuffner \& Paul 2004), the Great Barrier Reef (Birrell 2003, Birrell et al. 2005, in review) and Ningaloo reef in Western Australia (eastern Indian Ocean; Heyward \& Negri 1999). However, this work is disproportionately dominated by studies of enhancement by coralline algae (Tables 2 and 4). Only relatively recently has there been significant attention paid to the effects of algae involved in reef degradation, and this work remains insufficient to demonstrate clear patterns or relationships, such as between algal functional groups and different mechanisms for algal effects (Table 3; Appendix). Even at the level of functional groups, several mechanisms have not been studied at all. Relatively few algal taxa have been studied, although effects on settlement may be relatively specific (e.g., Harrington et al. 2004, Maypa \& Raymundo 2004, Kuffner et al. 2006, Nugues \& Szmant 2006). For example, crustose coralline algae are often lumped in assemblages, yet one or two species may play a fundamental role in coral settlement whereas others can be deleterious to coral settlement or post-settlement survival (e.g., Suzuki et al. 1998, Harrington 2004, Harrington et al. 2004, Kim et al. 2004, Kitamura et al. 2005).

In the few cases that have received repeated attention, effects appear variable, even contrasting or inconsistent, even for the same alga. For example, the foliose brown alga Lobophora variegata, widespread on damaged reefs, has been variously shown to have both positive (Morse et al. 1996, Birrell et al. in review) and negative (Baird \& Morse 2004, Kuffner et al. 2006) effects on coral settlement. Certainly, effects can vary considerably amongst algal taxa (Birrell et al. in review).

There is also discussion about the extent to which enhancement of settlement by crustose coralline algae is due to properties of the algae or of microbial biofilms present on the algae (see next section). The extent to which these apparent inconsistencies represent different processes, variability among individuals, or differences in methods remains unclear. For example, many studies use artificial substrata to facilitate microscopic examination, yet recruitment on to such substrata is often very different from that on natural substrata (often predominantly CCA; e.g., Morse et al. 1988, Mundy 2000, Raimondi \& Morse 2000, Birrell et al. in review).

\section{Positive effects of macroalgae on coral settlement}

As many as 25 algae, primarily calcareous red algae (CRA) and in particular crustose coralline algae have been observed to induce settlement of coral larvae (Table 4), although some controversy surrounds the identification of specific mechanisms for this induction. Morse et al. (1988, 1994), Morse et al. (1996) and Morse \& Morse (1991) suggested that coral settlement is induced by polysaccharide morphogens found in cell walls of CRA from both the Caribbean and the Pacific. In contrast, Heyward \& Negri (1999), Negri et al. (2001) and Webster et al. (2004) suggest the morphogens that 
induce coral settlement may be less specific and originate from bacterial communities associated with CCA and possibly coral skeletons. Furthermore, Baird \& Morse (2004) noted greater settlement (up to $80 \% \pm 20 \%$ mean \pm standard error of the mean [SEM]) in unfiltered versus filtered $(0.2$ $\mu \mathrm{m})$ seawater, suggesting a role for waterborne molecules. Negri et al. (2001) observed relatively specific settlement induction by 1 out of 20 bacterial strains (Pseudoalteromonas Strain A3 isolated from the coralline CCA Hydrolithon onkodes). Indeed, both algal and bacterially derived induction may operate simultaneously, or perhaps at different timings or spatial scales, and understanding of this aspect will clearly develop further as new studies emerge. The chemical recognition of settlement cues or morphogens may be common to all scleractinian corals regardless of mode of reproduction (brooder or gamete spawner) or geographic origin (Morse et al. 1996). Table 4 lists records of observed response to induction by 26 species of corals, and up to $55 \%$ of coral larvae collected in wild slicks were induced to settle in response to crustose coralline algae (Heyward \& Negri 1999).

Corals can demonstrate varying degrees of specificity in responses to inductive cues from crustose coralline algae, but some corals do appear to prefer a few specific algae. Baird \& Morse (2004) observed metamorphosis of Acropora palifera in response to 3 out of 10 algal taxa, but metamorphosis of Stylophora pistillata in response to 9 out of 10 algal taxa suggesting a more opportunistic life-history strategy. Heyward \& Negri (1999) observed settlement and metamorphosis of Acropora millepora larvae on seven different CRA, including upright, geniculate, branching corallines (Amphiroa) and non-corallines (Peyssonnelia), as well as on coral skeleton and CRA skeleton. In contrast, Morse et al. (1988) and Morse et al. (1996) observed algal induction of coral settlement to be relatively specific to algal species. Settlement and recruitment in the field also appears very species specific (Raimondi \& Morse 2000, Harrington 2004, Harrington et al. 2004, on natural substratum and settlement plates). Heyward \& Negri (1999) also observed approximately half of the larvae collected from two different mass spawning slicks of coral larvae to settle on a Peyssonnelia sp. (a non-coralline crustose red alga; Ningaloo Reef, Western Australia).

Examples of positive impacts on coral settlement from macroalgae other than CRA are relatively scarce (Table 4) but do exist and are supported by evidence of algal effects on other invertebrate larvae. In a study of waterborne influences of macroalgae on settlement of the coral Acropora millepora on to the crustose coralline alga Hydrolithon reinboldii, water treated with Lobophora variegata, a corticated foliose brown macroalgae, enhanced settlement and substratum testing behaviour prior to settlement (relative to controls and other algal treatments; Birrell 2003, Birrell et al. 2008), although other algae had inhibitory effects (see next section). In another study of waterborne effects, L. variegata apparently induced initial metamorphosis features (elongation) of Cyphastrea sp. coral larvae (Morse et al. 1996); such transformations precede settlement of a coral larva (Harrison \& Wallace 1990). However, Baird \& Morse (2004) report apparent avoidance behaviour of coral larvae in response to fragmented portions of Lobophora variegata. This apparent discrepancy may reflect differences amongst coral species or stages, or the effects of compounds released in response to tissue damage from fragmentation of the alga.

Nugues \& Szmant (2006) report settlement of as many as half of the larvae of the coral Favia fragum on surfaces of the articulated calcareous green alga Halimeda opuntia, despite availability of suitable rubble substrata. Coral larvae have also been recorded to settle on the frondose green alga Ulva fasciata (Vermeij et al. in press); settlement on algal fronds is likely to lead to dislodgement and mortality of the coral recruit. Maypa \& Raymundo (2004) found waterborne influences from the leathery macrophyte Sargassum polycystum (brown alga) and corticated foliose alga Laurencia papillosa (red alga) to enhance settlement of Pocillopora damicornis (up to $71 \% \pm 4 \%$ mean \pm SEM, approximately 3-fold relative to controls). Walters et al. (1996) found the macroalgae Padina australis (corticated foliose brown alga), Hypnea musciformis (corticated macrophyte, red alga) and Ulva fasciata (foliose green alga) from Hawai'ian reefs provided waterborne chemical 
cues that enhanced settlement of a polychaete (Hydroides elegans). Thus algae other than CCA can provide positive cues for larval settlement. This is a challenging point because many of the above fleshy algae are characteristic of more degraded reefs, so positive responses may seem counteradaptive. However, it may be that such responses are adaptive if they enhance the chances of larvae finding reef substratum from open water (off reef). Inducers characterised from CRA are generally insoluble in seawater (e.g., Morse et al. 1988, 1994, Morse et al. 1996) so it may be that signals from other algae serve to guide larvae in open water towards a reef substratum, before insoluble cues from CRA are detectable.

Work with algal-associated microbial biofilms and settlement of invertebrate larvae generally has suggested that these provide cues for invertebrate settlement, as well as the algae with which they are associated (Hoffman \& Brand 1987, Johnson et al. 1991a,b). As indicated above, recent work focused on coral settlement has found this to be partly true for at least three species of corals (Acropora millepora, A. willissae, A. microphthalma; Negri et al. 2001, Webster et al. 2004). Specific bacteria isolated from CCA (Hydrolithon onkodes) have been identified as inducers of coral settlement (Negri et al. 2001) and diverse bacterial communities alone (i.e., without calcareous or crustose algal substratum) have induced coral settlement (Webster et al. 2004). Thus, it is possible that the presence of microbial biofilms may contribute to the occasional surprising settlement of coral larvae on the surface of upright algae, such as observed for Halimeda opuntia (an upright, calcareous green alga unlikely to enhance coral survival; Nugues \& Szmant 2006 in Curação, Caribbean; this result probably also reflected the high abundance of planulae in this study, as suggested by the authors, or the presence of epiphytic CCA on the Halimeda). This suggestion is consistent with evidence that waterborne influences from $\mathrm{H}$. opuntia were not found to affect settlement of the coral Pocillopora damicornis (Maypa \& Raymundo 2004, central Philippines).

In summary, although interesting patterns for induction of coral by algae are beginning to emerge, these patterns are based on relatively few examples with many exceptions, the interactions appear complex and variable, and reliable generalisations are not yet in reach. Fortunately, this is an area of active research, with well-established methods and techniques, that promises continued rapid development.

\section{Negative effects of macroalgae on coral settlement}

\section{Chemical effects (allelopathy)}

Macroalgae may be a source of both waterborne and insoluble (tissue-attached) chemical cues that may either kill or damage larvae before they arrive and settle or may deter larvae from exploring a habitat and settling. Such chemical effects have been found in cyanobacteria, microalgae and macroalgae and have long been accepted to affect settlement of a range of invertebrate larvae (e.g., Pawlik 1992, Walters et al. 1996, 2003, de Nys \& Steinberg 1999, Gross 2003), although there are relatively few studies relevant to algal impacts on coral settlement (Table 3). Kuffner \& Paul (2004) observed that the presence of a cyanobacterium, Lyngbya majuscula, reduced larval survival of Acropora surculosa and settlement of Pocillopora damicornis on surfaces with high cover of a crustose coralline alga (unidentified). Kuffner et al. (2006) reported negative influences of the cyanobacteria Lyngbya polychroa and L. confervoides and several algae (Dictyota pulchella, Lobophora variegata, and Chondrophycus poiteaui) on presettlement behaviour of larvae of Porites astreoides, also in the Caribbean. Maypa \& Raymundo (2004), also working with Pocillopora damicornis, observed that, although waterborne influences from Sargassum polycystum and Laurencia papillosa promoted coral settlement, in both cases unsettled larvae died within $24 \mathrm{~h}$ and all spat died after 10 days in the Sargassum polycystum treatment. Baird \& Morse (2004) observed no settlement of planulae from either Stylophora pistillata or Acropora palifera in treatments with fragments of Lobophora sp. and planulae stopped swimming, sank and remained motionless for 
the duration of their observations. Birrell (2003) and Birrell et al. (2008) observed that Acropora millepora larvae avoided substratum testing behaviour in response to waterborne influences from the alga Chlorodesmis fastigiata, despite the presence of a crustose coralline alga known to induce settlement (Hydrolithon reinboldii; e.g., Morse et al. 1996, Harrington 2004).

Studies of filamentous algal effects on mature corals have shown some species can cause tissue necrosis, apparently due to allelopathic chemicals (Corallophila huysmansii and Anotrichium tenue on massive Porites spp.; Jompa \& McCook 2003a,b). It is likely that such effects may inhibit coral settlement or kill coral larvae upon contact. It is relevant here that species of crustose coralline algae have been reported to show allelopathic inhibition of settlement of macroalgae (Suzuki et al. 1998, Kim et al. 2004). Recent work has shown complex interactions between apparent chemical effects of algae and effects of microbes on coral settlement (Vermeij et al. in press). This area merits further research effort because chemically mediated inhibition of coral settlement by macroalgae has the potential to significantly increase the extent of impacts well beyond their occupation of space, with serious consequences for coral population replenishment and resilience.

\section{Epithallial sloughing}

Algae that periodically shed surface epithallial tissue layers, known as epithallial sloughing, can effectively reduce fouling organisms (including corals) by providing an unstable and short-lived surface for attachment (Johnson \& Mann 1986, Keats et al. 1997, Littler \& Littler 1999, Harrington et al. 2004). Epithallial sloughing is particularly common amongst crustose coralline algae and effectively prevents fouling by filamentous and other diminutive forms of algae. Algal overgrowth of such coralline algae can cause tissue death within 2 wk (Keats et al. 1997). This prevention of algal fouling may explain why live coralline algae are more appealing to coral larvae than dead corallines (Morse et al. 1996, Harrington et al. 2004). The mechanism of epithallial sloughing is predominantly reported for the red algal (Rhodophyta) families Corallinaceae, Sporolithaceae and Delesseriaceae (Johnson \& Mann 1986, Littler \& Littler 1999). Although sloughing is occasionally reported for other taxa, including some brown algae (Phaeophyceae; e.g., Moss 1982), these seem unlikely to play a major role in coral settlement. Epithallial sloughing may explain strong differences in suitability of crustose coralline algae as settlement substratum for corals (Harrington 2004, R.S. Steneck personal communication). Surveys of larval settlement of the corals Acropora millepora and A. tenuis on a range of crustose coralline algae demonstrated that those which provide unstable and renewed surfaces (e.g., Neogoniolithon fosliei, see Littler \& Littler 1999) tend to have reduced settlement, whereas greatest settlement is observed on species that do not slough epithallial layers (Harrington 2004, Harrington et al. 2004, R.S. Steneck personal communication). It is worth noting, however, that these differences may well reflect post-settlement mortality of spat, due to epithallial sloughing, and that coral settlement may actually be fairly indiscriminate (Harrington et al. 2004).

\section{Other habitat effects: shading, pre-emption of space and sediment trapping}

Many of the effects of algae on habitats previously identified (see pp. 33-40) can be assumed to have significant effects on coral settlement but published demonstrations of such impacts are scarce (Table 3). Certainly, the presence of algae has been shown to reduce coral settlement but the effects are variable and precise mechanisms or causes unclear. Birrell et al. (2005) tested the effect of two different filamentous algal turfs on settlement of the coral Acropora millepora; in one case the turf inhibited settlement relative to controls with turfs removed, and in the other there was no difference. Similar results were obtained by Petersen et al. (2005). Experimental removal of Sargassum canopy enhanced coral recruitment (Jompa 2001) and the development of Sargassum canopy, due to experimental exclusion of herbivores, caused reduced coral settlement compared with plots dominated by filamentous turf algae (Hughes et al. 2007), although it is possible that these results reflect 
post-settlement mortality rather than differential settlement. It would be very valuable to explore the relationship between inhibition of settlement and the height and density of algal assemblages, both within and between different algal assemblage types (e.g., comparisons of coral settlement in different turfs and between turfs and other algal assemblages such as Sargassum canopies). Birrell et al. (2005) suggested that the differences in turf height and/or thickness may have caused the different results for two turfs mentioned above.

Algal pre-emption of space and 'recruitment barriers' have been widely inferred (e.g., McCook et al. 2001a and references therein) but it is not entirely clear to what extent the effect is caused by physical pre-emption of space or by other factors. Dense turfs of the filamentous alga Enteromorpha intestinalis in culture apparently inhibited colonisation by spores of the alga Ulothrix pseudoflacca by space pre-emption (Hruby \& Norton 1979, Olson \& Lubchenco 1990). McCook et al. (2001a) suggest a continuous macroalgae canopy (e.g., foliose or corticated foliose algae) may reduce larval access to substratum below, and hence inhibit settlement. In the case of crustose algae, closely adherent foliose forms and thick, dense algal mats, this reduction of access may be effectively true. However, coral larvae are motile and relatively small (approximately 0.5- to 2-mm diameter; Harrison \& Wallace 1990) and so it is questionable whether either a filamentous turf or a Sargassum canopy could be effectively continuous to coral larvae; theoretically both have sufficient space between algal thalli for corals to gain access to substratum. Thus space pre-emption may to some extent be a scale-dependent concept. However, although algal assemblages may not strictly prevent access of coral larvae to substratum, it is clear that access will be substantially inhibited due to (1) entanglement, predation or allelopathy within the algal canopy, (2) metabolic costs of actively navigating through the canopy and (3) habitat effects on chemical and nutrient regimes, oxygenation, hydrodynamics or sediment trapping. The concept of a recruitment barrier may therefore be more relevant than strict space pre-emption.

Sediment trapping and accumulation by algae are likely to be a major limitation on access to substratum, potentially acting as a complete barrier, especially on degraded reefs exposed to high terrestrial run-off. In one of the few studies to consider interactions between human impacts and algal effects, Birrell et al. (2005) found that sediment trapping by filamentous turfs can reduce settlement of the coral Acropora millepora.

There is no direct evidence for algal shading affecting coral settlement and many coral larvae are not photosynthetic (Harrison \& Wallace 1990). However, both intensity and spectral quality can affect coral settlement (Mundy \& Babcock 1998) and Baird \& Hughes (2000) report that shade reduced overall coral recruitment by $96 \%$ (based on data from underneath plate corals at $2 \mathrm{~m}$ depth on a reef crest approximately $8 \mathrm{wk}$ after settlement, so that differences are probably at least partly due to post-settlement mortality). In contrast, Kuffner (2001) observed that reduced ultraviolet radiation favoured settlement of the coral Pocillopora damicornis. Thus algal impacts on coral settlement through shading are plausible but they are likely to differ between coral species and to depend on the extent and spectral quality of algal shading. Shading effects on settlement are probably less significant than shading effects on post-settlement survival and growth as photosynthesis becomes more important in later stages.

\section{Effects of macroalgae on the post-settlement survival and growth of corals}

The effects of benthic macroalgae on the post-settlement survival and growth of juvenile corals will be of major importance to the replenishment of coral populations after disturbances, in part because coral recruits are more vulnerable to a broader range of impacts than established corals. However, once again, these conclusions are based as much on conceptual considerations as empirical evidence due to the scarcity of published research (McCook et al. 2001a, Table 3, Figures 1 and 2, 
but see Box \& Mumby 2007). In contrast to studies of settlement, studies of recruitment and postsettlement have favoured larger-bodied upright fleshy algae (foliose and corticated foliose, leathery macrophytes), typical of 'phase shifts', mostly as a result of dramatic and long-term degradation of Caribbean reefs (Table 3). Significantly, coral post-settlement dynamics are of much longer duration, up to years, in contrast to the days to weeks between larval release and settlement (Harrison \& Wallace 1990), so that effects have longer to accumulate.

Algal effects on post-settlement survival of corals seem to be generally negative. The majority of studies in Table 3 reported impacts varying from mortality to reduced growth. It is important to consider sublethal effects as well as effects on survival/mortality because reduced growth rates or fitness may have important long-term consequences for population-level recovery (e.g., Box \& Mumby 2007). Examples of neutral or positive effects include survival of recruits on crustose and thin filamentous turfs (Birrell 2003, Harrington et al. 2004); algae sheltering or obscuring recruits, thus protecting them from damage by grazing herbivores or corallivores (e.g., Bak \& Vaneys 1975, Bak 1994, Miller \& Hay 1998); and shading of coral recruits from bleaching damage (Birrell 2003, and by analogy to Jompa 2001 for established corals).

Direct effects of algae on coral recruits (e.g., abrasion, overgrowth, epithallial sloughing) have received more attention than potential indirect effects, such as changes to physical and chemical habitat conditions or grazing regimes. However, as shown (pp. 33-40), changes to light levels, flow rates, chemical and nutrient regimes and sediment accumulation will all have potentially powerful impacts on fitness and growth of juvenile corals, and these warrant direct investigation. Other examples of possible indirect effects include incidental ('collateral') damage to recruits from grazers feeding on adjacent algae (e.g., Bak \& Vaneys 1975, Bak 1994) or obscuring of recruits (preceding paragraph). Potts (1977) suggested that damselfish behaviour may facilitate algal impacts on corals by favouring accumulation of algal biomass, although territorial defence may also reduce damage to coral recruits from larger herbivores (Sammarco \& Carleton 1981; see also Ceccarelli et al. 2001). Note that most of the preceding examples provide circumstantial evidence only and such indirect effects warrant direct investigation in the specific context of coral replenishment.

\section{Mechanisms for algal effects on post-settlement corals}

The mechanisms for direct impacts of algae on coral recruits are essentially those identified for mature coral-algal interactions (McCook et al. 2001b), namely overgrowth/smothering, shading, abrasion and chemical effects (but omitting recruitment barriers and epithallial sloughing, both of which affect settlement and were addressed on pp. 45-46). Table 3 summarises available evidence for each of these mechanisms, classified against the algal functional groups involved; some of the combinations are not possible (e.g., crustose algae cannot generally shade or abrade). As indicated in McCook et al. (2001b; their Table 6), coral recruits are more vulnerable to many of these mechanisms than established corals because they are easier to overgrow or shade and generally more vulnerable to physiological effects. As suggested in that paper, the properties of the algae are likely to be more relevant than the properties of the coral recruits, which are still small and have limited development and differentiation (but see next section).

However, many areas have not received any research attention, and chemical effects, abrasion and sediment accumulation have been overlooked for a range of functional groups. For example, chemical or allelopathic effects seem likely for species from all functional groups (e.g., Walters et al. 2003), including crustose coralline algae (Suzuki et al. 1998, Kim et al. 2004, Kitamura et al. 2005), and the scarcity of reports presumably reflects lack of research (perhaps due to the technical requirements of such research) rather than indicating that such effects do not occur. McCook et al. (2001a; their Table 6) list the mechanisms they consider likely to be common for each algal functional group, emphasising overgrowth and shading for most groups, abrasion for the larger groups, 
sloughing for crustose algae and chemical effects for microalgae (such as cyanobacteria). A recent study by Box \& Mumby (2007) specifically tested the mechanisms involved, showing that effects of the widespread foliose, brown algae Lobophora variegata and Dictyota pulchella can in large part be attributed to shading and abrasion.

The strength of each mechanism (overgrowth/smothering, shading, abrasion, chemical effects) will vary with a range of factors including, in particular, the type, height and density of the algal assemblage. For example, abrasion by leathery and corticated macrophytes (e.g., Turbinaria spp. or Sargassum spp., both brown algal genera) is likely to be more severe than by foliose (e.g., Padina spp., brown alga) or filamentous algae (e.g., Chlorodesmis spp. green alga). Indeed Gleason (1996) observed Turbinaria spp. to completely remove coral recruits from settlement tiles (Turbinaria is a particularly tough and spiky, upright brown alga). However, a dense canopy of large leathery algae is likely to shelter coral recruits rather than abrade them. Abrasion from foliose algae (Ulva spp. green alga, Lobophora variegata, Dictyota menstrualis brown algae) does not appear to be as extreme, even when combined with shading and potentially chemical effects (e.g., Fairfull \& Harriott 1999, Kuffner et al. 2006). It is not practical to compare the relative strength of the different mechanisms because their effect will depend on the above factors in each circumstance.

All four mechanisms can be expected to increase in intensity with density, although abrasion may moderate if the assemblage is dense enough to limit frond movement. Height of the algal canopy will affect the morphologies that can be overgrown; generally, an algal turf or crust will not overgrow any but the smallest recruits, whereas a thick algal mat will overgrow most recruits, except upright, branching corals (Figures 1 and 2). Height will have a major effect on shading, with larger algae shading larger recruits, and well grazed algal turfs providing little effective shade. Other factors that will affect the strength of effects include water flow and wave action, which will increase the impact of abrasion on adjacent corals and recruits (e.g., River \& Edmunds 2001, Eckman et al. 2003).

\section{Size and morphological development of coral recruits}

Although coral recruits are initially relatively small and undifferentiated, as they grow, their size relative to adjacent algal assemblages and their morphology will both change, with consequences for their interactions with the algae. Coral survival has been shown generally to increase with growth, especially in the very early post-settlement period (Rylaarsdam 1983, Hughes \& Jackson 1985, Babcock \& Mundy 1996, Hughes \& Tanner 2000, Wilson \& Harrison 2005). Babcock \& Mundy (1996) showed that survival and development of older coral recruits ( $>5$ months) was greatest on upward facing surfaces with more light but that survival of younger corals was lower on these surfaces, possibly as a result of deleterious impacts of sediments. Thus corals are likely to be most vulnerable to algal impacts immediately after settlement, and vulnerability to different mechanisms is likely to change. For example, newly settled spat seem likely to be much more vulnerable to allelopathic impacts than established juvenile corals.

In particular, as the relative size of coral recruits changes relative to different algal types, the mechanisms of algal effects will change. Coral recruits greater than a few millimetres in height may emerge from a close-cropped filamentous turf (Figures 1 and 2), reducing the potential for shading and abrasion, and reducing the relative effects of flow regimes and chemical environments within the turf (e.g., Carpenter \& Williams 1993, Larkum et al. 2003). In contrast, very small recruits may be protected from abrasion caused by larger seaweeds by small-scale surface features. An example is provided by two simultaneous studies of a phase shift caused by experimental exclusion of herbivores. Experimental plots became overgrown by algae, predominantly Sargassum spp. (large, leathery brown macrophyte, up to $3 \mathrm{~m}$ tall) and Padina spp. (corticated foliose, brown alga), whereas control plots were dominated by closely cropped filamentous turfs. Hughes et al. (2007) found the 
larger algae inhibited survival of coral recruits (0.5- to 5.0-cm diameter), naturally recruiting on to the reef substratum. In contrast, in the same experimental plots, Birrell (2003) observed higher survival of smaller (diameters $<0.5 \mathrm{~cm}$ ) Acropora millepora spat transplanted within days after settlement and followed from individual polyps for 130 days. It appears the smaller size of the latter recruits meant they were less frequently in contact with the larger algae, were less frequently subject to abrasion and were less affected by shade (as suggested by Babcock \& Mundy's 1996 observations discussed in the first paragraph of this section). Indeed, algal canopies may have provided some protection to these very small recruits during a mild bleaching (Great Barrier Reef, summer of 2002, as suggested for adult corals, Jompa \& McCook 1998). Increasing size (perimeter, height and surface area, polyp number) of coral recruits may also increase intensity of competition for space, the range of other benthic organisms encountered and the range of different chemical and physical features of the habitat encountered (Jackson 1979).

As coral recruits grow, they increasingly express interspecific differences in morphological traits and life-history characteristics so that morphology will become increasingly relevant to the outcomes of interactions with algae. Although algal properties are particularly important (McCook et al. 2001a), it is also true that different corals interact differently, even with the same alga (e.g., Nugues \& Bak 2006 using Lobophora variegata). Furthermore, changes in size and morphology will interact. For example, growth of simple, rounded morphologies (e.g., favids) will be less significant to their interactions with algae than growth of upright branching morphologies (e.g., tabular or staghorn Acropora spp., which stand clear of the substratum and shade competitors; Baird \& Hughes 2000).

\section{Effects of spatial and temporal scale of algal dominance}

Moving from the level of individual coral recruits to the level of populations, the spatial scale and duration of interactions will have major consequences for the effects of algal assemblages on coral replenishment and reef resilience. The spatial extent of disturbances is critical to the nature of the consequent recovery and succession (McCook 1994, Connell et al. 1997, 2004, Folke et al. 2004). Localised disturbances such as storm damage, ship groundings or dynamite fishing can facilitate algal dominance and invasion on limited scales $\left(10^{2}-10^{4} \mathrm{~m}^{2}\right.$; e.g., Schaffelke et al. 2006 , Raymundo et al. 2007). Recovery from such degradation will involve external supply of coral larvae, encroachment from surrounding populations, and control of algal biomass by herbivores. In contrast, mass bleaching, large-scale run-off or widespread overfishing may lead to macroalgal dominance throughout entire regions (Hughes 1994, Jackson et al. 2001, McClanahan et al. 2001, Berkelmans et al. 2004). In such circumstances, larval supply may be seriously reduced at regional scales (e.g., Hughes \& Tanner 2000) and herbivory may be unable to control such large-scale algal increases, resulting in much more intense and more general algal inhibition of coral replenishment. Small-scale $\left(25-\mathrm{m}^{2}\right)$, experimentally induced phase shifts (Hughes et al. 2007) were reversed relatively rapidly (Bellwood et al. 2006) because diverse herbivore populations were present in adjacent undisturbed habitat, which would not be the case for reef-wide phase shifts. Even where disturbance is patchy, fragmentation of reef habitats may lead to reduction in overall larval supply, and overall survival and fitness of recruits, becoming a long-term threat to resilience (Hughes et al. 2005).

Similar considerations are relevant to the duration of algal dominance, with more severe degradation generally involving longer-term reductions in coral replenishment and greater loss of reef resilience. Decadal-scale algal 'phase shifts' on reefs in the Caribbean have led to widespread reductions in coral recruit survival, as well as death of mature colonies (Hughes 1994, Hughes \& Tanner 2000, Edmunds 2002, Rogers \& Miller 2006, Edmunds \& Elahi 2007). Indeed macroalgal impacts in the Caribbean have played a key role in changing reefs, apparently irreversibly, relative to their geological past (Pandolfi \& Jackson 2006). In contrast, experimental herbivore exclusion over 
2 yr reduced but did not completely inhibit recruit survival (Hughes et al. 2007). Seasonal blooms in algal biomass and overgrowth (on the scale of months; e.g., Diaz-Pulido \& Garzón-Ferreira 2002, Rogers 1997) may have minimal effects on coral replenishment, either because overgrowth is shortlived or because it is asynchronous with key life-cycle stages (e.g., spawning or settlement).

Overall, short-term and more localised dominance by macroalgae is likely to have less severe impacts on reef resilience, not simply because effects are less extensive, but also because effects are less intense within the patch. In such circumstances, if macroalgal dominance is localised and alleviated within years, long-term reef decline may be avoided. However, long-term and large-scale dominance by macroalgae will generally result in more sustained and more intense impacts on coral replenishment and consequent serious loss of reef resilience.

\section{Conclusions and overall implications for reef resilience}

Overall, it is clear that benthic macroalgae have a wide range of potentially major impacts on the different stages or processes of coral replenishment and that these effects are critical to the ecological resilience of coral reefs. Macroalgal 'phase shifts', especially those dominated by larger, fleshy algae or thick mats of algae, can hinder coral replenishment by reducing adult fecundity, larval dispersal, settlement and post-settlement growth and survival. In contrast, reef substratum dominated by crustose coralline algae and fine, closely grazed filamentous algal turfs is relatively well suited for coral replenishment. Importantly, effects on the processes of fecundity, larval dispersal, settlement and post-settlement growth and survival are cumulative and interdependent because to recruit successfully, a coral requires each stage to be successful.

Algal effects on coral larval supply, settlement and post-settlement survival are diverse, complex and highly variable, ranging from positive effects, such as induction of settlement on coralline crusts, to strongly negative effects, such as exclusion of settlement and recruitment by thick algal mats. In general, negative effects appear more common, especially for larger, fleshy algae or thick mats typical of phase shifts and degraded reefs. Algal effects on coral replenishment appear to be often specific to taxa or assemblages and functional groups and may include direct effects, such as direct overgrowth of coral recruits, and indirect effects, especially changes in the physical, chemical or microbial nature of habitats due to algal overgrowth.

Although numerous factors and circumstances will influence the outcomes, several key points are worth emphasising. The different processes or stages of coral replenishment respond very differently to different algal influences. Within each stage, variability in algal effects is strongly related to key properties of the algal assemblage, especially algal size, growth form or functional group, density and chemical properties, including nutrient processing, production of allelopathic secondary metabolites or effects on microbial communities. With the exception of chemical effects, most of these traits are well captured by the functional groups, such as crustose, filamentous and various upright fleshy groups. However, there is still considerable specificity among both algal and coral taxa, and the life-history traits of corals, especially their size and morphology, will become increasingly important as the corals grow.

It is clear that existing information on algal effects on coral replenishment is insufficient to adequately understand this critical aspect of reef resilience. All topics need further research, but algal effects on larval supply, effects of fleshy algae on coral settlement, effects of algae mediated by changes in microbial assemblages and several specific combinations of algal type and competitive mechanisms warrant particular attention. Effects of crustose coralline algae on coral settlement have been better studied than most aspects. There is a real need for careful attention to the nature and properties of the algae in these interactions and research should aim to resolve the algae studied to functional groups as a minimum, in addition to the best feasible taxonomic descriptions, and description of canopy heights, density and growth form. 
Overall, given algal dominance of degraded reefs, the review demonstrates the importance of more careful consideration of algal effects on coral replenishment to coral-reef resilience, in both scientific and management contexts. The nature of the algal assemblage arising from disturbances can vary from filamentous algal turfs to beds of large, canopy-forming algae (Table 1; Diaz-Pulido \& McCook 2002), and the differences in algal assemblages will have major impacts on the future of the reef (e.g., Table 3) and on the effectiveness of management strategies. Clearly, there is not yet sufficient evidence to draw strong conclusions about these differences but the urgency of impending degradation warrants some preliminary comments. Where algal communities are dominated by CCA and closely cropped filamentous turfs, coral replenishment is likely to be strongest. Blooms of seasonal algae may have a relatively low impact unless the bloom period overlaps with coral spawning and/or settlement periods. Canopies of large, leathery algae, such as Sargassum, are likely to seriously inhibit coral replenishment and recovery but the most severe impacts seem likely to arise with thick and dense mats of fleshy algae, which render most of the substratum inaccessible, especially in conjunction with heavy sediment deposition. The density of any algal assemblages will strongly influence the extent of such barriers and the extent of chemical and nutrient gradients.

Options for direct management responses to algal dominance are largely limited to proactive steps to prevent establishment of undesirable algal assemblages. Once established, there is little that can be done to remove algal blooms at any significant scale. Proactive strategies should aim to maximise the relative success of filamentous turfs and CCA, minimise the growth and accumulation of larger, fleshy algae and minimise the extent to which algae interact with anthropogenic sediments and nutrients. Perhaps most important is the protection of herbivore guilds, especially herbivorous fishes, which maintain low algal biomass, in turn enhancing coral recruitment (McCook 1999, Hughes et al. 2007, Mumby et al. 2007). Measures to reduce pollution, especially increased sediments, may reduce competitive dominance by larger, fleshy algae and will minimise sediment trapping and formation of detrimental chemical or microbial microhabitats within the algal assemblage.

More generally, measures that enhance the overall resilience of the reef ecosystem, such as maintaining coral health, ecosystem biodiversity and trophic structure and integrity (Hughes et al. 2003, McCook et al. 2007), will serve to maintain the capacity of the system to resist and recover from disturbances and indirectly slow or prevent increases in algal dominance. Particularly important is to reduce the frequency and severity of disturbances, such as coral bleaching and cyclones. Both disturbances and loss of resilience depend critically on climate change, and the most critical overall need is for urgent and dramatic actions to reduce the rate and extent of climate change, by reducing emissions of greenhouse gases.

Globally, increasing reef degradation, especially due to the impending impacts of changing climates (Hoegh-Guldberg et al. 2007), means that the extent and duration of algal dominance will increase and the effects of this dominance on coral replenishment are likely to cause a severe bottleneck for reef recovery. Although much attention has focused on the global-scale effects of climate change on corals as the primary reef builders, there has been less detailed consideration of climate effects on key processes and interactions, such as the interactions between algae and coral replenishment. Increasingly frequent and severe mass bleaching of corals will result in increasingly extensive algal colonisation of dead corals. But recent work (Diaz-Pulido et al. 2007b) has also shown that climate change, particularly ocean acidification, will have major effects on reef algae, probably enhancing dominance by turfing and fleshy algae and decreasing the abundance of CCA. Such changes will alter the context for coral replenishment, interacting synergistically with stresses on corals, and leading to increasing dominance by thicker algal mats and larger fleshy algae, in turn causing increased inhibition of coral replenishment. As climate change and other human impacts on coral reefs increase, understanding and addressing the changing dynamics of coral replenishment on algal-dominated reefs become increasingly important. 


\section{Acknowledgements}

We thank T.P. Hughes and R.S. Steneck for invaluable discussion and L. Harrington, C. Damiano and especially J. E. Smith for comments on the manuscript. We gratefully acknowledge the support of F. Birrell, L. Birrell, M. Birrell, J. Barendrecht, R. Bonaldo, Y. Tibiriça and C. Rodenas-Lopez to C.B. during the preparation of this review, and L.McC., C.B. and G.D.-P. acknowledge support from the Pew Fellowship Program in Marine Conservation.

\section{Appendix}

List of coral taxa and algae used in published studies of algal impacts on coral settlement or postsettlement survival. Approximately 800 species of corals have been taxonomically identified worldwide (Veron 2001).

\begin{tabular}{|c|c|c|}
\hline Coral & $\begin{array}{l}\text { Reproductive } \\
\text { mode }\end{array}$ & Macroalgae \\
\hline Acropora digitifera & $\mathrm{S}$ & Hydrolithon reinboldii ${ }^{1}$, Lobophora variegata ${ }^{1}$, Peyssonnelia sp. $^{1}$ \\
\hline Acropora florida & S & Hydrolithon reinboldii ${ }^{1}$, Lobophora variegata ${ }^{1}$, Peyssonnelia sp. $^{1}$ \\
\hline Acropora formosa & S & Hydrolithon reinboldii ${ }^{1}$, Lobophora variegata ${ }^{1}$, Peyssonnelia sp. $^{1}$ \\
\hline Acropora gemmifera & S & Hydrolithon reinboldii ${ }^{1}$, Lobophora variegata ${ }^{1}$, Peyssonnelia sp. $^{1}$ \\
\hline Acropora hyacinthus & S & Hydrolithon reinboldii ${ }^{1}$, Lobophora variegata ${ }^{1}$, Peyssonnelia sp. $^{1}$ \\
\hline Acropora microphthalma & S & Bacteria/microalgae $^{2}$ \\
\hline Acropora millepora & S & 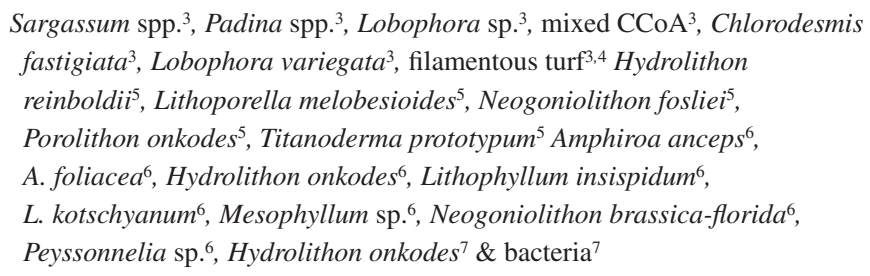 \\
\hline Acropora nasuta & S & Hydrolithon reinboldii ${ }^{1}$, Lobophora variegata ${ }^{1}$, Peyssonnelia sp. ${ }^{1}$ \\
\hline Acropora palifera & $\mathrm{B}$ & $\begin{array}{l}\text { Hydrolithon sp. }{ }^{8} \text {, Lobophora sp. }{ }^{8} \text {, Peyssonnelia } \text { sp. }^{8}, \text { Porolithon sp. }{ }^{8} \text {, } \\
\text { filamentous turf }(<15 \mathrm{~mm} \text { height in combination with } 10 \mathrm{~mm} \text { sediments })^{9}\end{array}$ \\
\hline Acropora sp. 1 & $\mathrm{~S}$ & Hydrolithon reinboldii ${ }^{1}$, Lobophora variegata ${ }^{1}$, Peyssonnelia sp. ${ }^{1}$ \\
\hline Acropora sp. 4 & $\mathrm{~S}$ & Hydrolithon sp. ${ }^{1}$, Lobophora sp. ${ }^{1}$, Peyssonnelia sp. ${ }^{1}$, Porolithon sp. ${ }^{1}$ \\
\hline Acropora sp. 6 & S & Lobophora variegata ${ }^{1}$ \\
\hline Acropora sp. 7 & $S$ & Peyssonnelia sp. ${ }^{1}$ \\
\hline Acropora spp. 8, 9, 10, 11 & S & Hydrolithon reinboldii ${ }^{1}$ \\
\hline Acropora surculosa & S & Lyngbya majuscula ${ }^{10}$ \\
\hline Acropora tenuis & S & $\begin{array}{l}\text { Hydrolithon reinboldii }{ }^{1,5}, \text { Lithoporella melobesioides }{ }^{5}, \text { Neogoniolithon } \\
\text { fosliei }^{5}, \text { Porolithon onkodes }^{5} \text {, Titanoderma prototypum }{ }^{5}, \text { Lobophora }^{1} \\
\text { variegata }^{1}, \text { Peyssonnelia } \text { sp. }^{1}\end{array}$ \\
\hline Acropora willisae & $\mathrm{S}$ & Lithophyllum sp. ${ }^{7}$ \\
\hline Agaricia agaricites & B & $\mathrm{CCoA}^{11}$, endolithic algae ${ }^{11}$, filamentous turfs ${ }^{11}$ \\
\hline Agaricia danai & $\mathrm{B}$ & Microalgae/bacteria ${ }^{12}$, mixed CCoA both on dead Millepora complanata \\
\hline Agaricia humilis & $\mathrm{B}$ & $\begin{array}{l}\text { CCoA sp. } 1^{12}, \text { sp. } 2^{12}, \text { sp. } 3^{12}, \text { sp. } 4^{12}, \text { sp. } 5^{12}, \text { Hildenbrandia sp. }{ }^{12} \text {, microalgae } \\
\text { or bacteria }{ }^{12} \text {, mixed CCoA }{ }^{12} \text {, Porolithon sp. }{ }^{12}\end{array}$ \\
\hline Agaricia humilis & B & $\begin{array}{l}\text { Hydrolithon boergensi } i^{1,13,14,17,18} \text {, H. reinboldii }{ }^{1}, \text { Neogoniolithon } \\
\text { megacarpum }{ }^{13,18} \text {, Porolithon pachydermum }{ }^{13} \text {, Peyssonnelia } \text { sp. }{ }^{1} \text {, Halimeda } \\
\text { opuntia }^{15} \text {, filamentous turfs (thick \& ungrazed; thin \& grazed; primarily } \\
\text { Cladophora spp. \& Cladophoropsis spp. })^{16} ; \text { mixed CCoA }(\text { Hydrolithon, } \\
\text { Mesophyllum, Pneophyllum, Porolithon \& Titanoderma })^{16} \text {, unidentified } \\
\text { CCoA }^{11} \text {, endolithic algae }{ }^{11} \text {, filamentous turfs }{ }^{11}\end{array}$ \\
\hline
\end{tabular}




\begin{tabular}{|c|c|c|}
\hline Coral & $\begin{array}{l}\text { Reproductive } \\
\text { mode }\end{array}$ & Macroalgae \\
\hline Agaricia tenuifolia & B & Hydrolithon boergensii ${ }^{13}$, microalgae/bacteria ${ }^{12}$, mixed $\mathrm{CCoA}^{12}$ \\
\hline Agaricia spp. & $\mathrm{B}$ & Lobophora variegata ${ }^{24}$, Dictyota pulchella ${ }^{24}$ \\
\hline Cyphastrea sp. & $\mathrm{S}$ & Hydrolithon reinboldii ${ }^{1}$, Lobophora variegata ${ }^{1}$, Peyssonnelia sp. $^{1}$ \\
\hline Favia favus & $\mathrm{S}$ & Hydrolithon reinboldii ${ }^{1}$, Lobophora variegata ${ }^{1}$, Peyssonnelia sp. $^{1}$ \\
\hline Favia fragum & B & $\begin{array}{l}\text { Halimeda opuntia }{ }^{15} \text {, filamentous turfs (thick \& ungrazed; thin \& grazed; } \\
\text { primarily Cladophora spp. \& Cladophoropsis spp. })^{16} \text {, mixed CCoA } \\
(\text { Hydrolithon, Mesophyllum, Pneophyllum, Porolithon \& Titanoderma) })^{16}\end{array}$ \\
\hline Gonioastrea retiformis & $\mathrm{S}$ & Hydrolithon reinboldii ${ }^{1}$, Lobophora variegata ${ }^{1}$, Peyssonnelia sp. $^{1}$ \\
\hline Montipora capitata & S & $\begin{array}{l}\text { Ulva fasciata }^{25} \text {, Acanthophora spicifera }{ }^{25} \text {, Pterocladiella caerulescens }{ }^{25} \text {, } \\
\text { Sargassum polyphyllum }{ }^{25}\end{array}$ \\
\hline Oculina arbuscula & & $\begin{array}{l}\text { Sargassum spp. }{ }^{19} \text {, Dictyota spp. } .^{19} \text {, Dictyopteris spp. }{ }^{19} \text {, Zonaria spp. }{ }^{19} \text {, } \\
\text { Lobophora spp. }{ }^{19}\end{array}$ \\
\hline Pocillopora damicornis & B & $\begin{array}{l}\text { Lyngbya majuscula }{ }^{10}, \text { L. confervoides }{ }^{20}, \text { Halimeda opuntia }{ }^{20}, \text { Laurencia } \\
\text { papillosa }^{20}, \text { Peysonnelia rubra }{ }^{20}, \text { Sargassum polycystum }{ }^{20}\end{array}$ \\
\hline Porites astreoides & B & $\begin{array}{l}\text { Chondrophycus poiteaui/Laurencia poiteaui } i^{21}, \text { Dictyota confervoides }{ }^{21} \text {, } \\
\text { D. menstrualis }{ }^{21}, \text { D. pinnatifida }{ }^{21}, \text { D. pulchella }{ }^{21}, \text { Lobophora variegata }^{21} \text {, } \\
\text { L. polychroa }{ }^{21} \text {, induced algal phase shift by herbivore exclusion }{ }^{22}\end{array}$ \\
\hline Porites porites & $\mathrm{B}$ & Sargassum hystrix ${ }^{23}$ \\
\hline Stylophora pistillata & $\mathrm{B}$ & Hydrolithon sp. ${ }^{8}$, Lobophora sp. ${ }^{8}$, Peyssonnelia sp. ${ }^{8}$, Porolithon sp. ${ }^{8}$ \\
\hline Tubastrea aurea & $\mathrm{B}$ & Hydrolithon boergensii ${ }^{13}$ \\
\hline
\end{tabular}

Note: Coral reproductive mode is listed as brooders (B) and spawners (S; mode unknown for Oculina arbuscula). Superscript numbers indicate references as follows: ${ }^{1}$ Morse et al. 1996, ${ }^{2}$ Webster et al. 2004, ${ }^{3}$ Birrell 2003, ${ }^{4}$ Birrell et al. 2005, ${ }^{5}$ Harrington et al. 2004, ${ }^{6}$ Heyward \& Negri 1999, ${ }^{7}$ Negri et al. 2001, ${ }^{8}$ Baird \& Morse 2004, ${ }^{9}$ Potts 1977, ${ }^{10}$ Kuffner \& Paul 2004, ${ }^{11}$ Van Moorsel 1985, ${ }^{12}$ Morse et al. 1988, ${ }^{13}$ Morse \& Morse 1991, ${ }^{14}$ Morse et al. 1994, ${ }^{15}$ Nugues \& Szmant 2006, ${ }^{16}$ Petersen et al. 2005, ${ }^{17}$ Raimondi \& Morse 2000, ${ }^{18}$ Steneck \& Morse (cited in Morse \& Morse 1991), ${ }^{19}$ Miller \& Hay 1996, ${ }^{20}$ Maypa \& Raymundo 2004, ${ }^{21}$ Kuffner et al. 2006, ${ }^{22}$ Lewis 1986, ${ }^{23}$ River \& Edmunds 2001, ${ }^{24}$ Box \& Mumby 2007, ${ }^{25}$ Vermeij et al. in press.

\section{References}

Abelson, A. \& Denny, M. 1997. Settlement of marine organisms in flow. Annual Review of Ecology and Systematics 28, 317-339.

Amsler, C.D., Reed, D.C. \& Neushul, M. 1992. The microclimate inhabited by macroalgal propagules. British Phycological Journal 27, 253-270.

Anthony, K.R.N., Hoogenboom, M.O. \& Connolly, S.R. 2005. Adaptive variation in coral geometry and the optimization of internal colony light climates. Functional Ecology 19, 17-26.

Anthony, K.R.N. \& Svane, I. 1994. Effects of flow habitat on body size and reproductive patterns in the sea anemone Metridium senile in the Gullmarsfjord, Sweden. Marine Ecology Progress Series 113, 257-269.

Babcock, R. 1988. Fine scale spatial and temporal patterns in coral settlement. In Proceedings of the 6th International Coral Reef Symposium, J.H. Choat et al. (eds). Townsville, Australia: James Cook University, 635-639.

Babcock, R. \& Davies, P. 1991. Effects of sedimentation on settlement of Acropora millepora. Coral Reefs $\mathbf{9}$, 205-208.

Babcock, R. \& Mundy, C. 1996. Coral recruitment: consequences of settlement choice for early growth and survivorship in two scleractinians. Journal of Experimental Marine Biology and Ecology 206, 179-201. 
Baird, A.H. \& Hughes, T.P. 1997. Spatial variation in coral recruitment around Lizard Island, Australia. In Proceedings of the 8th International Coral Reef Symposium, H.A. Lessios \& I.G. Macintyre (eds). Panama: Smithsonian Tropical Research Institute, 1207-1211.

Baird, A.H. \& Hughes, T.P. 2000. Competitive dominance by tabular corals: an experimental analysis of recruitment and survival of understorey assemblages. Journal of Experimental Marine Biology and Ecology 251, 117-132.

Baird, A.H. \& Morse, A.N.C. 2004. Induction of metamorphosis in larvae of the brooding corals Acropora palifera and Stylophora pistillata. Marine and Freshwater Research 55, 469-472.

Baird, A.H., Pratchett, M.S., Gibson, D.J., Koziumi, N. \& Marquis, C.P. 2001. Variable palatability of coral eggs to a planktivorous fish. Marine and Freshwater Research 52, 865-868.

Bak, R.P.M. 1994. Sea urchin bioerosion on coral reefs: place in the carbonate budget and relevant variables. Coral Reefs 13, 99-103.

Bak, R.P.M. \& Engel, M.S. 1979. Distribution, abundance and survival of juvenile hermatypic corals (Scleractinia) and the importance of life-history strategies in the parent coral community. Marine Biology 54, 341-352.

Bak, R.P.M. \& Vaneys, G. 1975. Predation of sea urchin Diadema antillarum philippi on living coral. Oecologia 20, 111-115.

Banks, S.A. \& Harriott, V.J. 1996. Patterns of coral recruitment at the Gneering Shoals, southeast Queensland, Australia. Coral Reefs 15, 225-230.

Barnes, D.J. \& Chalker, B.E. 1990. Calcification and photosynthesis in reef-building corals and algae. In Ecosystems of the World 25: Coral Reefs, Z. Dubinsky (ed.). Amsterdam: Elsevier, 109-132.

Becerro, M.A., Bonito, V. \& Paul, V.J. 2006. Effects of monsoon-driven wave action on coral reefs of Guam and implications for coral recruitment. Coral Reefs 25, 193-199.

Bellwood, D.R. 1996. Production and reworking of sediment by parrotfishes (family Scaridae) on the Great Barrier Reef, Australia. Marine Biology 125, 795-800.

Bellwood, D.R. \& Choat, J.H. 1990. A functional analysis of grazing in parrotfishes (family Scaridae): the ecological implications. Environmental Biology of Fishes 28, 189-214.

Bellwood, D.R., Hughes, T.P. \& Hoey, A.S. 2006. Sleeping functional group drives coral-reef recovery. Current Biology 16, 2434-2439.

Bergey, E.A., Boettiger, C.A. \& Resh, V.H. 1995. Effects of water velocity on the architecture and epiphytes of Cladophora glomerata (Chlorophyta). Journal of Phycology 31, 264-271.

Berkelmans, R., De'ath, G., Kininmonth, S. \& Skirving, W.J. 2004. A comparison of the 1998 and 2002 coral bleaching events on the Great Barrier Reef: spatial correlation, patterns, and predictions. Coral Reefs 23, 74-83.

Birkeland, C. 1977. The importance of rate of biomass accumulation in early successional stages of benthic communities to the survival of coral recruits. In Proceedings of the 3rd International Coral Reef Symposium, D.L. Taylor et al. (eds). Miami: Rosenstiel School of Marine and Atmospheric Science, $15-21$.

Birrell, C.L. 2003. Influences of benthic algae on coral settlement and post-settlement survival: implications for the recovery of disturbed and degraded reefs. M.Sc. thesis, James Cook University, Townsville, Australia.

Birrell, C.L., McCook, L.J. \& Willis, B.L. 2005. Effects of algal turfs and sediment on coral settlement. Marine Pollution Bulletin 51, 408-414.

Birrell, C.L., McCook, L.J., Willis, B.L. \& Harrington, L. 2008. Allelochemical effects of macroalgae on larval settlement of the coral Acropora millepora. Marine Ecology Progress Series, in press.

Bouchon, C. 1985. Quantitative study of scleractinian coral communities of Tiahura reef (Mooorea, French Polynesia). In Proceedings of the 5th International Coral Reef Symposium, C. Gabrie \& B. Salvat (eds). Tahiti: Antenne Museum des Hautes Etudes, French Polynesia, 279-290.

Box, S.J. \& Mumby, P.J. 2007. Effect of macroalgal competition on growth and survival of juvenile Caribbean corals. Marine Ecology Progress Series 342, 139-149.

Brock, R.E. 1979. Experimental study on the effects of grazing by parrotfishes and role of refuges in benthic community structure. Marine Biology 51, 381-388.

Bruno, J.F., Selig, E.R., Casey, K.S., Page, C.A., Willis, B.L., Harvell, C. D., Sweatman, H. \& Melendy, A.M. 2007. Thermal stress and coral cover as drivers of coral disease outbreaks. Public Library of Science Biology 5 (6), 1-8. 
Bryant, D., Burke, L., McManus, J. \& Spalding, M. 1998. Reefs at Risk: A Map-Based Indicator of the Threats to the World's Coral Reefs. Washington, DC: World Resources Institute, International Center for Living Aquatic Resources Management, World Conservation Monitoring Centre, and United Nations Environment Programme.

Carpenter, R.C. 1990. Competition among marine macroalgae: a physiological perspective. Journal of Phycology 26, 6-12.

Carpenter, R.C. \& Edmunds, P.J. 2006. Local and regional scale recovery of Diadema promotes recruitment of scleractinian corals. Ecology Letters 9, 268-277.

Carpenter, R.C., Hackney, J.M. \& Adey, W.H. 1991. Measurements of primary productivity and nitrogenase activity of coral reef algae in a chamber incorporating oscillatory flow. Limnology and Oceanography 36, 40-49.

Carpenter, R.C. \& Williams, S.L. 1993. Effects of algal turf canopy height and microscale substratum topography on profiles of flow speed in a coral fore-reef environment. Limnology and Oceanography 38, 687-694.

Ceccarelli, D.M., Jones, G.P. \& McCook, L.J. 2001. Territorial damselfishes as determinants of the structure of benthic communities on coral reefs. Oceanography and Marine Biology An Annual Review 39, $355-389$.

Cheroske, A.G., Williams, S.L. \& Carpenter, R.C. 2000. Effects of physical and biological disturbances on algal turfs in Kaneohe Bay, Hawaii. Journal of Experimental Marine Biology and Ecology 248, 1-34.

Chittaro, P.M. 2004. Fish-habitat associations across multiple spatial scales. Coral Reefs 23, 235-244.

Connell, J.H., Hughes, T.P. \& Wallace, C.C. 1997. A 30-year study of coral abundance, recruitment, and disturbance at several scales in space and time. Ecological Monographs 67, 461-488.

Connell, J.H., Hughes, T.P., Wallace, C.C., Tanner, J.E., Harms, K.E. \& Kerr, A.M. 2004. A long-term study of competition and diversity of corals. Ecological Monographs 74, 179-210.

Cox, E. 2007. Continuation of sexual reproduction in Montipora capitata following bleaching. Coral Reefs 26, $721-724$.

Cuet, P., Naim, G., Faure, G. \& Conan, J.Y. 1988. Nutrient-rich ground water impact on benthic communities in la Saline reef (Reunion Island, Indian Ocean): preliminary results. In Proceedings of the 6th International Coral Reef Symposium, J.H. Choat et al. (eds). Townsville, Australia: James Cook University of North Queensland, 207-212.

de Nys, R. \& Steinberg, P.D. 1999. Role of secondary metabolites from algae and seagrasses in biofouling control. In Recent Advances in Marine Biotechnology, Vol. 3, M. Fingerman et al. (eds). Enfield, New Hampshire: Science Publishers, 223-244.

Diaz-Pulido, G., Chin, A., Davidson, J. \& McCook, L.J. 2007a. Cyclone promotes rapid colonisation of benthic diatoms in the Great Barrier Reef. Coral Reefs 26, 787.

Diaz-Pulido, G. \& Garzón-Ferreira, J. 2002. Seasonality in algal assemblages on upwelling-influenced coral reefs in the Colombian Caribbean. Botanica Marina 45, 284-292.

Diaz-Pulido, G. \& McCook, L.J. 2002. The fate of bleached corals: patterns and dynamics of algal recruitment. Marine Ecology Progress Series 232, 115-128.

Diaz-Pulido, G. \& McCook, L.J. 2004. Algal recruitment and interactions. Coral Reefs 23, 225-233.

Diaz-Pulido, G. \& McCook, L.J. in press. Environmental status of the Great Barrier Reef: macroalgae (seaweeds). In State of the Great Barrier Reef Report, A. Chin (ed.). Townsville, Australia: Great Barrier Reef Marine Park Authority.

Diaz-Pulido, G., McCook, L.J., Larkum, A.W.D., Lotze, H.K., Raven, J.A., Schaffelke, B., Smith, J.E. \& Steneck, R.S. 2007b. Vulnerability of macroalgae of the Great Barrier Reef to climate change. In Climate Change and the Great Barrier Reef, P. Marshall \& J. Johnson (eds). Townsville, Australia: Great Barrier Reef Marine Park Authority, 153-192.

Done, T.J. 1992. Phase-shifts in coral reef communities and their ecological significance. Hydrobiologia 247, 121-132.

Duggins, D.O., Eckman, J.E. \& Sewell, A.T. 1990. Ecology of understory kelp environments: 2. Effects of kelps on recruitment of benthic invertebrates. Journal of Experimental Marine Biology and Ecology 143, 27-45.

Dunstan, P.K. \& Johnson, C.R. 1998. Spatio-temporal variation in coral recruitment at different scales on Heron Reef, southern Great Barrier Reef. Coral Reefs 17, 71-81. 
Eckman, J.E., Duggins, D.O. \& Siddon, C.E. 2003. Current and wave dynamics in the shallow subtidal: implications to the ecology of understory and surface-canopy kelps. Marine Ecology Progress Series 265, 45-56.

Edmunds, P.J. 2002. Long-term dynamics of coral reefs in St. John, U.S. Virgin Islands. Coral Reefs 21, 357-367.

Edmunds, P.J. \& Carpenter, R.C. 2001. Recovery of Diadema antillarum reduces macroalgal cover and increases abundance of juvenile corals on a Caribbean reef. Proceedings of the National Academy of Sciences of the United States of America 98, 5067-5071.

Edmunds, P.J. \& Elahi, R. 2007. The demographics of a 15-year decline in cover of the Caribbean reef coral Montastraea annularis. Ecological Monographs 77, 3-18.

Edmunds, P.J., Gates, R.D. \& Gleason, D.F. 2001. The biology of larvae from the reef coral Porites astreoides, and their response to temperature disturbances. Marine Biology 139, 981-989.

Epstein, N., Bak, R.P.M. \& Rinkevich, J. 2000. Toxicity of third generation dispersants and dispersed Egyptian crude oil on Red Sea coral larvae. Marine Pollution Bulletin 40, 497-503.

Fabricius, K.E. 2005. Effects of terrestrial runoff on the ecology of corals and coral reefs: review and synthesis. Marine Pollution Bulletin 50, 125-146.

Fabricius, K.E. \& Metzner, J. 2004. Scleractinian walls of mouths: predation on coral larvae by corals. Coral Reefs 23, 245-248.

Fabricius, K.E., Wild, C., Wolanski, E. \& Abele, D. 2003. Effects of transparent exopolymer particles and muddy terrigenous sediments on the survival of hard coral recruits. Estuarine Coastal and Shelf Science 57, 613-621.

Fairfull, S.J.L. \& Harriott, V.J. 1999. Succession, space and coral recruitment in a subtropical fouling community. Marine and Freshwater Research 50, 235-242.

Faure, G. 1989. Degradation of coral reefs at Moorea Island (French Polynesia) by Acanthaster plancii. Journal of Coastal Research 5, 295-306.

Fearon, R.J. \& Cameron, A.M. 1996. Larvotoxic extracts of the hard coral Goniopora tenuidens: allelochemicals that limit settlement of potential competitors? Toxicon 34, 361-367.

Fearon, R.J. \& Cameron, A.M. 1997. Preliminary evidence supporting the ability of hermatypic corals to affect adversely larvae and early settlement stages of hard coral competitors. Journal of Chemical Ecology 23, 1769-1780.

Fisk, D.A. \& Harriott, V.J. 1990. Spatial and temporal variation in coral recruitment on the Great Barrier Reef: implications for dispersal hypotheses. Marine Biology 107, 485-490.

Folke, C., Carpenter, S., Walker, B., Scheffer, M., Elmqvist, T., Gunderson, L. \& Holling, C.S. 2004. Regime shifts, resilience, and biodiversity in ecosystem management. Annual Review of Ecology Evolution and Systematics 35, 557-581.

Furnas, M. 2003. Catchments and Corals: Terrestrial Run-Off to the Great Barrier Reef. Townsville, Australia: Australian Institute of Marine Science.

Gabrie, C., Porcher, M. \& Masson, M. 1985. Dredging in French Polynesian reefs: towards a general policy of resource exploitation and site development. In Proceedings of the 5th International Coral Reef Symposium, C. Gabrie \& B. Salvat (eds). Tahiti: Antenne Museum des Hautes Etudes, French Polynesia, 271-277.

Gilmour, J. 1999. Experimental investigation into the effects of suspended sediment on fertilisation, larval survival and settlement in a scleractinian coral. Marine Biology 135, 451-462.

Gleason, M.G. 1996. Coral recruitment in Moorea, French Polynesia: the importance of patch type and temporal variation. Journal of Experimental Marine Biology and Ecology 207, 79-101.

Gross, E.M. 2003. Allelopathy of aquatic autotrophs. Critical Reviews in Plant Sciences 22, 313-339.

Hall, V.R. \& Hughes, T.P. 1996. Reproductive strategies of modular organisms: comparative studies of reefbuilding corals. Ecology 77, 950-963.

Harrington, L. 2004. Ecology of crustose coralline algae; interactions with scleractinian corals and responses to environmental conditions. Ph.D. thesis. James Cook University, Townsville, Australia.

Harrington, L., Fabricius, K., De'Ath, G. \& Negri, A. 2004. Recognition and selection of settlement substrata determine post-settlement survival in corals. Ecology 85, 3428-3437.

Harriott, V.J. 1985. Recruitment patterns of scleractinian corals at Lizard Island, Great Barrier Reef. In Proceedings of the 5th International Coral Reef Symposium, C. Gabrie \& B. Salvat (eds). Tahiti: Antenne Museum des Hautes Etudes, French Polynesia, 367-372. 


\section{ALGAL EFFECTS ON CORAL REPLENISHMENT AND REEF RESILIENCE}

Harriott, V.J. 1992. Recruitment patterns of scleractinian corals in an isolated subtropical reef system. Coral Reefs 11, 215-219.

Harriott, V.J. \& Fisk, D.A. 1988. Recruitment patterns of scleractinian corals: a study of three reefs. Australian Journal of Marine and Freshwater Research 39, 409-416.

Harrison, P.L. \& Wallace, C.C. 1990. Reproduction, dispersal and recruitment of scleractinian corals. In Ecosystems of the World 25: Coral Reefs, Z. Dubinsky (ed.). Amsterdam: Elsevier, 133-207.

Harrison, P.L. \& Ward, S. 2001. Elevated levels of nitrogen and phosphorus reduce fertilisation success of gametes from scleractinian reef corals. Marine Biology 139, 1057-1068.

Hay, M.E. 1981. The functional morphology of turf-forming seaweeds: persistence in stressful marine habitats. Ecology 62, 739-750.

Haynes, D. \& Michalek-Wagner, K. 2000. Water quality in the Great Barrier Reef World Heritage Area: past perspectives, current issues and new research directions. Marine Pollution Bulletin 41, 428-434.

Heyward, A.J. \& Negri, A.P. 1999. Natural inducers for coral larval metamorphosis. Coral Reefs 18, 273-279.

Hodgson, G. 1990. Sediment and the settlement of larvae of the reef coral Pocillopora damicornis. Coral Reefs 9, 41-43.

Hoegh-Guldberg, O. 1999. Climate change, coral bleaching and the future of the world's coral reefs. Marine and Freshwater Research 50, 839-866.

Hoegh-Guldberg, O., Mumby, P.J., Hooten, A.J., Steneck, R.S., Greenfield, P., Gomex, E., Harvell, C.D., Sale, P.F., Edwards, A.J., Caldeira, K., Knowlton, N., Eakin, C.M., Iglesias-Prieto, R., Muthiga, M., Bradbury, R.H., Dubi, A. \& Hatziolos, M.E. 2007. Coral reefs under rapid climate change and ocean acidification. Science 318, 1737-1742.

Hoffman, D.K. \& Brand, U. 1987. Induction of metamorphosis in the symbiotic scyphozoan Cassiopea andromeda: role of marine bacteria and of biochemicals. Symbiosis 4, 99-116.

Hoogenboom, M.O., Anthony, K.R.N. \& Connolly, S.R. 2006. Energetic cost of photoinhibition in corals. Marine Ecology Progress Series 313, 1-12.

Hruby, T. \& Norton, T.A. 1979. Algal colonization on rocky shores in the Firth of Clyde. Journal of Ecology 67, 65-77.

Hughes, T.P. 1985. Life histories and population dynamics of early successional corals. In Proceedings of the 5th International Coral Reef Symposium, C. Gabrie \& B. Salvat (eds). Tahiti: Antenne Museum des Hautes Etudes, French Polynesia, 101-106.

Hughes, T.P. 1989. Community structure and diversity of coral reefs: the role of history. Ecology 70, 275-279.

Hughes, T.P. 1994. Catastrophes, phase-shifts, and large-scale degradation of a Caribbean coral reef. Science 265, 1547-1551.

Hughes, T.P. 1996. Demographic approaches to community dynamics: a coral reef example. Ecology 77, 2256-2260.

Hughes, T.P., Baird, A.H., Bellwood, D.R., Card, M., Connolly, S.R., Folke, C., Grosberg, R., Hoegh-Guldberg, O., Jackson, J.B.C., Kleypas, J., Lough, J.M., Marshall, P., Nystrom, M., Palumbi, S.R., Pandolfi, J.M., Rosen, B. \& Roughgarden, J. 2003. Climate change, human impacts, and the resilience of coral reefs. Science 301, 929-933.

Hughes, T.P., Baird, A.H., Dinsdale, E.A., Moltschaniwskyj, N.A., Pratchett, M.S., Tanner, J.E. \& Willis, B.L. 1999. Patterns of recruitment and abundance of corals along the Great Barrier Reef. Nature 397, 59-63.

Hughes, T.P., Baird, A.H., Dinsdale, E.A., Moltschaniwskyj, N.A., Pratchett, M.S., Tanner, J.E. \& Willis, B.L. 2000. Supply-side ecology works both ways: the link between benthic adults, fecundity, and larval recruits. Ecology 81, 2241-2249.

Hughes, T.P., Bellwood, D.R., Folke, C., Steneck, R.S. \& Wilson, J. 2005. New paradigms for supporting the resilience of marine ecosystems. Trends in Ecology \& Evolution 20, 380-386.

Hughes, T.P. \& Connell, J.H. 1999. Multiple stressors on coral reefs: a long-term perspective. Limnology and Oceanography 44, 932-940.

Hughes, T.P. \& Jackson, J.B.C. 1985. Population dynamics and life histories of foliaceous corals. Ecological Monographs 55, 141-166.

Hughes, T.P., Reed, D.C. \& Boyle, M.J. 1987. Herbivory on coral reefs: community structure following mass mortalities of sea urchins. Journal of Experimental Marine Biology and Ecology 113, 39-59. 
Hughes, T.P., Rodrigues, M.J., Bellwood, D.R., Ceccarelli, D., Hoegh-Guldberg, O., McCook, L., Moltschaniwskyj, N., Pratchett, M.S., Steneck, R.S. \& Willis, B. 2007. Phase shifts, herbivory, and the resilience of coral reefs to climate change. Current Biology 17, 360-365.

Hughes, T.P. \& Tanner, J.E. 2000. Recruitment failure, life histories, and long-term decline of Caribbean corals. Ecology 81, 2250-2263.

Jackson, G.R. \& Winnant, C.D. 1983. Effects of a kelp forest on coastal currents. Continental Shelf Research 2, 75-80.

Jackson, J.B.C. 1979. Overgrowth competition between encrusting cheilostome ectoprocts in a Jamaican cryptic reef environment. Journal of Animal Ecology 48, 805-823.

Jackson, J.B.C., Kirby, M.X., Berger, W.H., Bjorndal, K.A., Botsford, L.W., Bourque, B.J., Bradbury, R.H., Cooke, R., Erlandson, J., Estes, J.A., Hughes, T.P., Kidwell, S., Lange, C.B., Lenihan, H.S., Pandolfi, J.M., Peterson, C.H., Steneck, R.S., Tegner, M.J. \& Warner, R.R. 2001. Historical overfishing and the recent collapse of coastal ecosystems. Science 293, 629-638.

Johnson, C.R. \& Mann, K.H. 1986. The crustose coralline alga, Phymatolithon foslie, inhibits the overgrowth of seaweeds without relying on herbivores. Journal of Experimental Marine Biology and Ecology 96, $127-146$.

Johnson, C.R., Muir, D.G. \& Reysenbach, A.L. 1991a. Characteristic bacteria associated with surfaces of coralline algae: a hypothesis for bacterial induction of marine invertebrate larvae. Marine Ecology Progress Series 74, 281-294.

Johnson, C.R., Sutton, D.C., Olson, R.R. \& Giddins, R. 1991b. Settlement of crown-of-thorns starfish: role of bacteria on surfaces of coralline algae and a hypothesis for deep-water recruitment. Marine Ecology Progress Series 71, 143-162.

Jompa, J. 2001. Interactions between macroalgae and scleractinian corals in the context of reef degradation. $\mathrm{Ph} . \mathrm{D}$. thesis, James Cook University, Townsville, Australia.

Jompa, J. \& McCook, L.J. 1998. Seaweeds save the reef?!: Sargassum canopy decreases coral bleaching on inshore reefs. Reef Research $\mathbf{8}, 5$.

Jompa, J. \& McCook, L.J. 2003a. Contrasting effects of turf algae on corals: massive Porites spp. are unaffected by mixed-species turfs, but killed by the red alga Anotrichium tenue. Marine Ecology Progress Series 258, 79-86.

Jompa, J. \& McCook, L.J. 2003b. Coral-algal competition: macroalgae with different properties have different effects on corals. Marine Ecology Progress Series 258, 87-95.

Karlson, R.H. 1999. Dynamics of Coral Communities. Dordrecht: Kluwer.

Keats, D.W., Knight, M.A. \& Pueschel, C.M. 1997. Antifouling effects of epithallial shedding in three crustose coralline algae (Rhodophyta, Coralinales) on a coral reef. Journal of Experimental Marine Biology and Ecology 213, 281-293.

Kim, J., Choi, J.S., Kang, S.E., Cho, J.Y., Jin, H.J., Chun, B.S. \& Hong, Y.K. 2004. Multiple allelopathic activity of the crustose coralline alga Lithophyllum yessoense against settlement and germination of seaweed spores. Journal of Applied Phycology 16, 175-179.

Kitamura, M., Koyama, T., Nakano, Y. \& Uemura, D. 2005. Corallinafuran and corallinaether, novel toxic compounds from crustose coralline red algae. Chemistry Letters 34, 1272-1273.

Kitamura, M., Koyama, T., Nakano, Y. \& Uemura, D. 2007. Characterization of a natural inducer of coral larval metamorphosis. Journal of Experimental Marine Biology and Ecology 340, 96-102.

Kline, D.I., Kuntz, N.M., Breitbart, M., Knowlton, N. \& Rohwer, F. 2006. Role of elevated organic carbon levels and microbial activity in coral mortality. Marine Ecology Progress Series 314, 119-125.

Knowlton, N. \& Jackson, J.B.C. 2001. The ecology of coral reefs. In Marine Community Ecology, M.D. Bertness et al. (eds). Sunderland, Massachusetts: Sinauer, 395-422.

Koh, E.G.L. \& Sweatman, H. 2000. Chemical warfare among scleractinians: bioactive natural products from Tubastraea faulkneri Wells kill larvae of potential competitors. Journal of Experimental Marine Biology and Ecology 251, 141-160.

Kuffner, I.B. 2001. Effects of ultraviolet (UV) radiation on larval settlement of the reef coral Pocillopora damicornis. Marine Ecology Progress Series 217, 251-261.

Kuffner, I.B. \& Paul, V.J. 2004. Effects of the benthic cyanobacterium Lyngbya majuscula on larval recruitment of the reef corals Acropora surculosa and Pocillopora damicornis. Coral Reefs 23, 455-458. 
Kuffner, I.B., Walters, L.J., Becerro, M.A., Paul, V.J., Ritson-Williams, R. \& Beach, K.S. 2006. Inhibition of coral recruitment by macroalgae and cyanobacteria. Marine Ecology Progress Series 323, 107-117.

Kuhl, M., Cohen, Y., Dalsgaard, T., Jorgensen, B.B. \& Revsbech, N.P. 1995. Microenvironment and photosynthesis of zooxanthellae in scleractinian corals studied with microsensors for $\mathrm{O}_{2}, \mathrm{pH}$ and light. Marine Ecology Progress Series 117, 159-172.

Larkum, A.W.D., Koch, E.M.W. \& Kuhl, M. 2003. Diffusive boundary layers and photosynthesis of the epilithic algal community of coral reefs. Marine Biology 142, 1073-1082.

Lesser, M.P. 1997. Oxidative stress causes coral bleaching during exposure to elevated temperatures. Coral Reefs 16, 187-192.

Lessios, H.A. 1988. Mass mortality of Diadema antillarum in the Caribbean: what have we learned? Annual Review of Ecology and Systematics 19, 371-393.

Lewis, S.M. 1986. The role of herbivorous fishes in the organization of a Caribbean reef community. Ecological Monographs 56, 183-200.

Lindquist, N. 1996. Palatability of invertebrate larvae to corals and sea anemones. Marine Biology 126, $745-755$.

Littler, M.M. 1980. Morphological form and photosynthetic performances of marine macroalgae: tests of a functional form hypothesis. Botanica Marina 23, 161-165.

Littler, M.M. \& Littler, D.S. 1980. The evolution of thallus form and survival strategies in benthic marine macroalgae: field and laboratory tests of a functional form model. American Naturalist 116, 25-44.

Littler, M.M. \& Littler, D.S. 1999. Epithallus sloughing: a self-cleaning mechanism for coralline algae. Coral Reefs 18, 204 only.

Littler, M.M., Littler, D.S. \& Taylor, P.R. 1983. Evolutionary strategies in a tropical barrier reef system: functional form groups of marine macroalgae. Journal of Phycology 19, 229-237.

Maida, M., Sammarco, P.W. \& Coll, J.C. 1995a. Effects of soft corals on scleractinian coral recruitment: I. Directional allelopathy and inhibition of settlement. Marine Ecology Progress Series 121, 191-202.

Maida, M., Sammarco, P.W. \& Coll, J.C. 1995b. Preliminary evidence for directional allelopathic effects of the soft coral Sinularia flexibilis (Alcyonacea, Octocorallia) on scleractinian coral recruitment. Bulletin of Marine Science 56, 303-311.

Markey, K.L., Baird, A.H., Humphrey, C. \& Negri, A.P. 2007. Insecticides and a fungicide affect multiple coral life stages. Marine Ecology Progress Series 330, 127-137.

Martin-Smith, K.M. 1993. Abundance of mobile epifauna: the role of habitat complexity and predation by fishes. Journal of Experimental Marine Biology and Ecology 174, 243-260.

Maypa, A.P. \& Raymundo, L.J. 2004. Algae-coral interactions: mediation of coral settlement, early survival, and growth by macroalgae. Silliman Journal 45, 76-95.

McClanahan, T.R. 2000. Bleaching damage and recovery potential of Maldivian coral reefs. Marine Pollution Bulletin 40, 587-597.

McClanahan, T.R., Maina, J., Starger, C.J., Herron-Perez, P. \& Dusek, E. 2005. Detriments to post-bleaching recovery of corals. Coral Reefs 24, 230-246.

McClanahan, T.R. \& Muthiga, N.A. 1998. An ecological shift in a remote coral atoll of Belize over 25 years. Environmental Conservation 25, 122-130.

McClanahan, T.R., Muthiga, N.A. \& Mangi, S. 2001. Coral and algal changes after the 1998 coral bleaching: interaction with reef management and herbivores on Kenyan reefs. Coral Reefs 19, 380-391.

McConnaughey, T.A., Adey, W.H. \& Small, A.M. 2000. Community and environmental influences on reef coral calcification. Limnology and Oceanography 45, 1667-1671.

McCook, L.J. 1994. Understanding ecological community succession: causal models and theories, a review. Vegetatio 110, 115-147.

McCook, L.J. 1996. Effects of herbivores and water quality on Sargassum distribution on the central Great Barrier Reef: cross-shelf transplants. Marine Ecology Progress Series 139, 179-192.

McCook, L.J. 1999. Macroalgae, nutrients and phase shifts on coral reefs: scientific issues and management consequences for the Great Barrier Reef. Coral Reefs 18, 357-367.

McCook, L.J. 2001. Competition between corals and algal turfs along a gradient of terrestrial influence in the nearshore central Great Barrier Reef. Coral Reefs 19, 419-425. 
McCook, L.J., Folke, C., Hughes, T.P., Nystrom, M., Obura, D. \& Salm, R. 2007. Ecological resilience, climate change and the Great Barrier Reef: an introduction. In Climate Change and the Great Barrier Reef, P. Marshall \& J. Johnson (eds). Townsville, Australia: Great Barrier Reef Marine Park Authority, 75-96.

McCook, L.J., Jompa, J. \& Diaz-Pulido, G. 2001a. Competition between corals and algae on coral reefs: a review of evidence and mechanisms. Coral Reefs 19, 400-417.

McCook, L.J., Wolanski, E. \& Spagnol, S. 2001b. Modelling and visualizing interactions between natural disturbances and eutrophication as causes of coral reef degradation. In Physics Biology Links in the GBR, E. Wolanski (ed.). Boca Raton, Florida: CRC Press, 113-125.

Michalek-Wagner, K. \& Willis, B.L. 2001. Impacts of bleaching on the soft coral Lobophytum compactum: I. Fecundity, fertilization and offspring viability. Coral Reefs 19, 231-239.

Miller, M.W. \& Barimo, J. 2001. Assessment of juvenile coral populations at two reef restoration sites in the Florida Keys National Marine Sanctuary: indicators of success? Bulletin of Marine Science 69, 395-405.

Miller, M.W. \& Hay, M.E. 1996. Coral-seaweed-grazer-nutrient interactions on temperate reefs. Ecological Monographs 66, 323-344.

Miller, M.W. \& Hay, M.E. 1998. Effects of fish predation and seaweed competition on the survival and growth of corals. Oecologia 113, 231-238.

Morse, A.N.C., Iwao, K., Baba, M., Shimoike, K., Hayashibara, T. \& Omori, M. 1996. An ancient chemosensory mechanism brings new life to coral reefs. Biological Bulletin (Woods Hole) 191, 149-154.

Morse, D.E., Hooker, N., Morse, A.N.C. \& Jensen, R.A. 1988. Control of larval metamorphosis and recruitment in sympatric agariciid corals. Journal of Experimental Marine Biology and Ecology 116, 193-217.

Morse, D.E. \& Morse, A.N.C. 1991. Enzymatic characterization of the morphogen recognized by Agaricia humilis (scleractinian coral) larvae. Biological Bulletin (Woods Hole) 181, 104-122.

Morse, D.E., Morse, A.N.C., Raimondi, P.T. \& Hooker, N. 1994. Morphogen based chemical flypaper for Agaricia humilis coral larvae. Biological Bulletin (Woods Hole) 186, 172-181.

Moss, B.L. 1982. The control of epiphytes by Halidris siliquosa (L.) Lyngb. (Phaeophyta, Cystoceiraceae). Phycologia 21, 185-191.

Muko, S., Kawasaki, K., Sakai, K., Takasu, F. \& Shigesada, N. 2000. Morphological plasticity in the coral Porites sillimaniani and its adaptive significance. Bulletin of Marine Science 66, 225-239.

Mumby, P.J. 1999. Bleaching and hurricane disturbances to populations of coral recruits in Belize. Marine Ecology Progress Series 190, 27-35.

Mumby, P.J., Harborne, A.R., Williams, J., Kappel, C.V., Brumbaugh, D.R., Micheli, F., Colmes, K.E., Dahlgren, C.P., Paris, C.B. \& Blackwell, P.G. 2007. Trophic cascade facilitates coral recruitment in a marine reserve. Proceedings of the National Academy of Sciences of the United States of America 104, 8362-8367.

Mundy, C. \& Babcock, R. 2000. Are vertical distribution patterns of scleractinian corals maintained by pre- or post-settlement processes? A case study of three contrasting species. Marine Ecology Progress Series 198, 109-119.

Mundy, C.N. 2000. An appraisal of methods used in coral recruitment studies. Coral Reefs 19, 124-131.

Mundy, C.N. \& Babcock, R.C. 1998. Role of light intensity and spectral quality in coral settlement: implications for depth-dependent settlement? Journal of Experimental Marine Biology and Ecology 223, 235-255.

Negri, A.P. \& Heyward, A.J. 2001. Inhibition of coral fertilisation and larval metamorphosis by tributyltin and copper. Marine Environmental Research 51, 17-27.

Negri, A.P., Vollhardt, C., Humphrey, C., Heyward, A.J., Jones, R., Eaglesham, G. \& Fabricius, K.E. 2005. Effects of the herbicide diuron on the early life history stages of coral. Marine Pollution Bulletin 51, $370-383$.

Negri, A.P., Webster, N.S., Hill, R.T. \& Heyward, A.J. 2001. Metamorphosis of broadcast spawning corals in response to bacteria isolated from crustose algae. Marine Ecology Progress Series 223, 121-131.

Nugues, M.M. \& Bak, R.P.M. 2006. Differential competitive abilities between Caribbean coral species and a brown alga: a year of experiments and a long-term perspective. Marine Ecology Progress Series 315, 75-86.

Nugues, M.M. \& Roberts, C.M. 2003. Coral mortality and interaction with algae in relation to sedimentation. Coral Reefs 22, 507-516. 
Nugues, M.M., Smith, G.W., Hooidonk, R.J., Seabra, M.I. \& Bak, R.P.M. 2004. Algal contact as a trigger for coral disease. Ecology Letters 7, 919-923.

Nugues, M.M. \& Szmant, A.M. 2006. Coral settlement onto Halimeda opuntia: a fatal attraction to an ephemeral substrate? Coral Reefs 25, 585-591.

Oliver, J. \& Babcock, R. 1992. Aspects of the fertilization ecology of broadcast spawning corals: sperm dilution effects and in situ measurements of fertilization. Biological Bulletin (Woods Hole) 183, 409-417.

Oliver, J.K., Chalker, B.E. \& Dunlap, W.C. 1983. Bathymetric adaptations of reef-building corals at Davies Reef, Great Barrier Reef, Australia: I. Long-term growth responses of Acropora formosa (Dana 1846). Journal of Experimental Marine Biology and Ecology 73, 11-35.

Oliver, J.K. \& Willis, B.L. 1987. Coral spawn slicks in the Great Barrier Reef: preliminary observations. Marine Biology 94, 521-529.

Olson, A.M. \& Lubchenco, J. 1990. Competition in seaweeds: linking plant traits to competitive outcomes. Journal of Phycology 26, 1-6.

Ostrander, G.K., Armstrong, K.M., Knobbe, E.T., Gerace, D. \& Scully, E.P. 2000. Rapid transition in the structure of a coral reef community: the effects of coral bleaching and physical disturbance. Proceedings of the National Academy of Sciences of the United States of America 97, 5297-5302.

Pandolfi, J.M. \& Jackson, J.B.C. 2006. Ecological persistence interrupted in Caribbean coral reefs. Ecology Letters 9, 818-826.

Pandolfi, J.M., Jackson, J.B.C., Baron, N., Bradbury, R.H., Guzman, H.M., Hughes, T.P., Kappel, C.V., Micheli, F., Ogden, J.C., Possingham, H.P. \& Sala, E. 2005. Ecology — are U.S. coral reefs on the slippery slope to slime? Science 307, 1725-1726.

Pawlik, J.R. 1992. Chemical ecology of the settlement of benthic marine invertebrates. Oceanography and Marine Biology An Annual Review 30, 273-335.

Payri, P.E. \& Naim, O. 1982. Variations entre 1971 et 1980 de la biomass et de la composition des populations de macroalgues sur le recife corallien de Tiahura (Ile de Moorea, Polynesis Francaise). Algologie 3, 229-240.

Petersen, D., Laterveer, M. \& Schuhmacher, H. 2005. Spatial and temporal variation in larval settlement of reefbuilding corals in mariculture. Aquaculture 249, 317-327.

Potts, D.C. 1977. Suppression of coral populations by filamentous algae within damselfish territories. Journal of Experimental Marine Biology and Ecology 28, 207-216.

Pratchett, M.S., Gust, N., Goby, G. \& Klanten, S.O. 2001. Consumption of coral propagules represents a significant trophic link between corals and reef fish. Coral Reefs 20, 13-17.

Purcell, S.W. 2000. Association of epilithic algae with sediment distribution on a windward reef in the northern Great Barrier Reef, Australia. Bulletin of Marine Science 66, 199-214.

Quan-Young, L.I. \& Espinoza-Avalos J. 2006. Reduction of zooxanthellae density, chlorophyll a concentration, and tissue thickness of the coral Montastrea faveolata (Scleractinia) when competing with mixed turf algae. Limnology and Oceanography 51, 1159-1166.

Raimondi, P.T. \& Morse, A.N.C. 2000. The consequences of complex larval behavior in a coral. Ecology 81, 3193-3211.

Ramade, F. \& Roche, H. 2006. Pollutant effects on coral reefs ecosystems. La Terre Et La Vie 61, 3-33.

Raymundo, L.J., Maypa, A.P., Gomez, E.D. \& Cadiz, P. 2007. Can dynamite-blasted reefs recover? A novel, low-tech approach to stimulating natural recovery in fish and coral populations. Marine Pollution Bulletin 54, 1009-1019.

Reed, D.C. \& Foster, M.S. 1984. The effects of canopy shading on algal recruitment and growth in a giant kelp forest. Ecology 65, 937-948.

Reichelt-Brushett, A.J. \& Harrison, P.L. 2000. The effect of copper on the settlement success of larvae from the scleractinian coral Acropora tenuis. Marine Pollution Bulletin 41, 385-391.

Richmond, R.H. 1985. Reversible metamorphosis in coral planula larvae. Marine Ecology Progress Series 22, 181-185.

Riegl, B. \& Branch, G.M. 1995. Effects of sediment on the energy budgets of four scleractinian (Bourne 1900) and five alcyonacean (Lamouroux 1816) corals. Journal of Experimental Marine Biology and Ecology 186, 259-275.

River, G.F. \& Edmunds, P.J. 2001. Mechanisms of interaction between macroalgae and scleractinians on a coral reef in Jamaica. Journal of Experimental Marine Biology and Ecology 261, 159-172. 
Rogers, C.S. 1990. Responses of coral reefs and reef organisms to sedimentation. Marine Ecology Progress Series 62, 185-202.

Rogers, C.S. \& Miller, J. 2006. Permanent 'phase shifts' or reversible declines in coral cover? Lack of recovery of two coral reefs in St. John, US Virgin Islands. Marine Ecology Progress Series 306, 103-114.

Rogers, R.W. 1997. Brown algae on Heron reef flat, Great Barrier Reef, Australia: spatial, seasonal and secular variation in cover. Botanica Marina 40, 113-117.

Rylaarsdam, K.W. 1983. Life histories and abundance patterns of colonial corals on Jamaican reefs. Marine Ecology Progress Series 13, 249-260.

Salvat, B. 1987. Human Impacts on Coral Reefs: Facts and Recommendations. Moorea, French Polynesia: Antenne Museum des Hautes Etudes.

Sammarco, P.W. 1980. Diadema and its relationship to coral spat mortality: grazing, competition, and biological disturbance. Journal of Experimental Marine Biology and Ecology 45, 245-272.

Sammarco, P.W. 1982. Polyp bail-out: an escape response to environmental stress and a new means of reproduction in corals. Marine Ecology Progress Series 10, 57-65.

Sammarco, P.W. 1991. Geographically specific recruitment and post-settlement mortality as influences on coral communities: the cross continental shelf transplant experiment. Limnology and Oceanography 36, 496-514.

Sammarco, P.W. \& Andrews, J.C. 1989. The Helix experiment: differential localized dispersal and recruitment patterns in Great Barrier Reef corals. Limnology and Oceanography 34, 896-912.

Sammarco, P.W. \& Carleton, J.H. 1981. Damselfish territoriality and coral community structure: reduced grazing, coral recruitment and effects of coral spat. In Proceedings of the 4th International Coral Reef Symposium, E.D. Gomez et al. (eds). Manila: University of the Philippines, 525-535.

Schaffelke, B., Smith, J.E. \& Hewitt, C.L. 2006. Introduced macroalgae: a growing concern. Journal of Applied Phycology 18, 529-541.

Smith, J.E., Shaw, M., Edwards, R.A., Obura, D., Pantos, O., Sala, E., Sandin, S.A., Smriga, S., Hatay, M. \& Rohwer, F.L. 2006. Indirect effects of algae on coral: algae-mediated, microbe-induced coral mortality. Ecology Letters 9, 835-845.

Smith, S.V., Kimmener, W.J., Laws, E.A., Brock, R.E. \& Walsh, T.W. 1981. Kaneohe Bay sewage diversion experiment: perspectives on ecosystem responses to nutritional perturbation. Pacific Science 35, 279-295.

Stamski, R.E. \& Field, M.E. 2006. Characterization of sediment trapped by macroalgae on a Hawaiian reef flat. Estuarine Coastal and Shelf Science 66, 211-216.

Steneck, R.S. 1997. Crustose corallines, other algal functional groups, herbivores and sediments: complex interactions along reef productivity gradients. In Proceedings of the 8th International Coral Reef Symposium, H.A. Lessios \& I.G. Macintyre (eds). Panama: Smithsonian Tropical Research Institute, 695-700.

Steneck, R.S. \& Dethier, M.N. 1994. A functional group approach to the structure of algal dominated communities. Oikos 69, 476-498.

Storlazzi, C.D., Brown, E.K. \& Field, M.E. 2006. The application of acoustic Doppler current profilers to measure the timing and patterns of coral larval dispersal. Coral Reefs 25, 369-381.

Suzuki, Y., Takabayashi, T., Kawaguchi, T. \& Matsunaga, K. 1998. Isolation of an allelopathic substance from the crustose coralline algae, Lithophyllum spp., and its effect on the brown alga, Laminaria religiosa Miyabe (Phaeophyta). Journal of Experimental Marine Biology and Ecology 225, 69-77.

Tanner, J.E. 1995. Competition between scleractinian corals and macroalgae: an experimental investigation of coral growth, survival and reproduction. Journal of Experimental Marine Biology and Ecology 190, $151-168$.

Titlyanov, E.A. 1991. Light adaptation and production characteristics of branches differing by age and illumination of the hermatypic coral Pocillopora verrucosa. Symbiosis 10, 249-260.

Underwood, A.J. 1999. Publication of so-called 'negative' results in marine ecology. Marine Ecology Progress Series 191, 307-309.

Valiela, I., McClelland, J., Hauxwell, J., Behr, P.J., Hersh, D. \& Foreman, K. 1997. Macroalgal blooms in shallow estuaries: controls and ecophysiological and ecosystem consequences. Limnology and Oceanography 42, 1105-1118. 
Van Moorsel, G.W.N.M. 1985. Disturbance and growth of juvenile corals (Agaricia humilis and Agaricia agaricites, Scleractinia) in natural habitats on the reef of Curação. Marine Ecology Progress Series 24, 99-112.

Vermeij, M.J.A. \& Bak, R.P.M. 2002. How are coral populations structured by light? Marine light regimes and the distribution of Madracis. Marine Ecology Progress Series 233, 105-116.

Vermeij, M.J.A., Smith, J.E., Sandin, S.A. \& Smith, C.M. in press. Survival and settlement succes of coral planulae: synergistic and independent effects of macroalgae and microbes. Oecologia.

Veron, J.E.N. 2001. Corals of the world. Townsville, Australia: Australian Institute of Marine Science.

Vogel, S. 1994. Life in Moving Fluids: The Physical Biology of Flow. Princeton, New Jersey: Princeton University Press.

Wallace, C.C. 1985a. Reproduction, recruitment and fragmentation in nine sympatric species of the coral genus Acropora. Marine Biology 88, 217-233.

Wallace, C.C. 1985b. Seasonal peaks and annual fluctuations in recruitment of juvenile scleractinian corals. Marine Ecology Progress Series 21, 289-298.

Wallace, C.C. \& Bull, G.D. 1981. Patterns of juvenile coral recruitment on a reef front during a spring-summer spawning period. In Proceedings of the 4th International Coral Reef Symposium, E.D. Gomez et al. (eds). Manila: University of the Philippines, 345-350.

Walters, L.J., Hadfield, M.G. \& Smith, C.M. 1996. Waterborne chemical compounds in tropical macroalgae: positive and negative cues for larval settlement. Marine Biology 126, 383-393.

Walters, L.J., Smith, C.M. \& Hadfield, M.G. 2003. Recruitment of sessile marine invertebrates on Hawaiian macrophytes: do pre-settlement or post-settlement processes keep plants free from fouling? Bulletin of Marine Science 72, 813-839.

Webster, N.S., Smith, L.D., Heyward, A.J., Watts, J.E.M., Webb, R.I., Blackall, L.L. \& Negri, A.P. 2004. Metamorphosis of a scleractinian coral in response to microbial biofilms. Applied and Environmental Microbiology 70, 1213-1221.

Wilkinson, C. 2004. Status of Coral Reefs of the World: 2004. Townsville, Australia: Australian Institute of Marine Science.

Willis, B.L. \& Oliver, J.K. 1990. Direct tracking of coral larvae: implications for dispersal studies of planktonic larvae in topographically complex environments. Ophelia 32, 145-162.

Wilson, J. \& Harrison, P. 2005. Post-settlement mortality and growth of newly settled reef corals in a subtropical environment. Coral Reefs 24, 418-421.

Wing, S.R., Leichter, J.J. \& Denny, M.W. 1993. A dynamic model for wave induced light fluctuations in a kelp forest. Limnology and Oceanography 38, 396-407. 

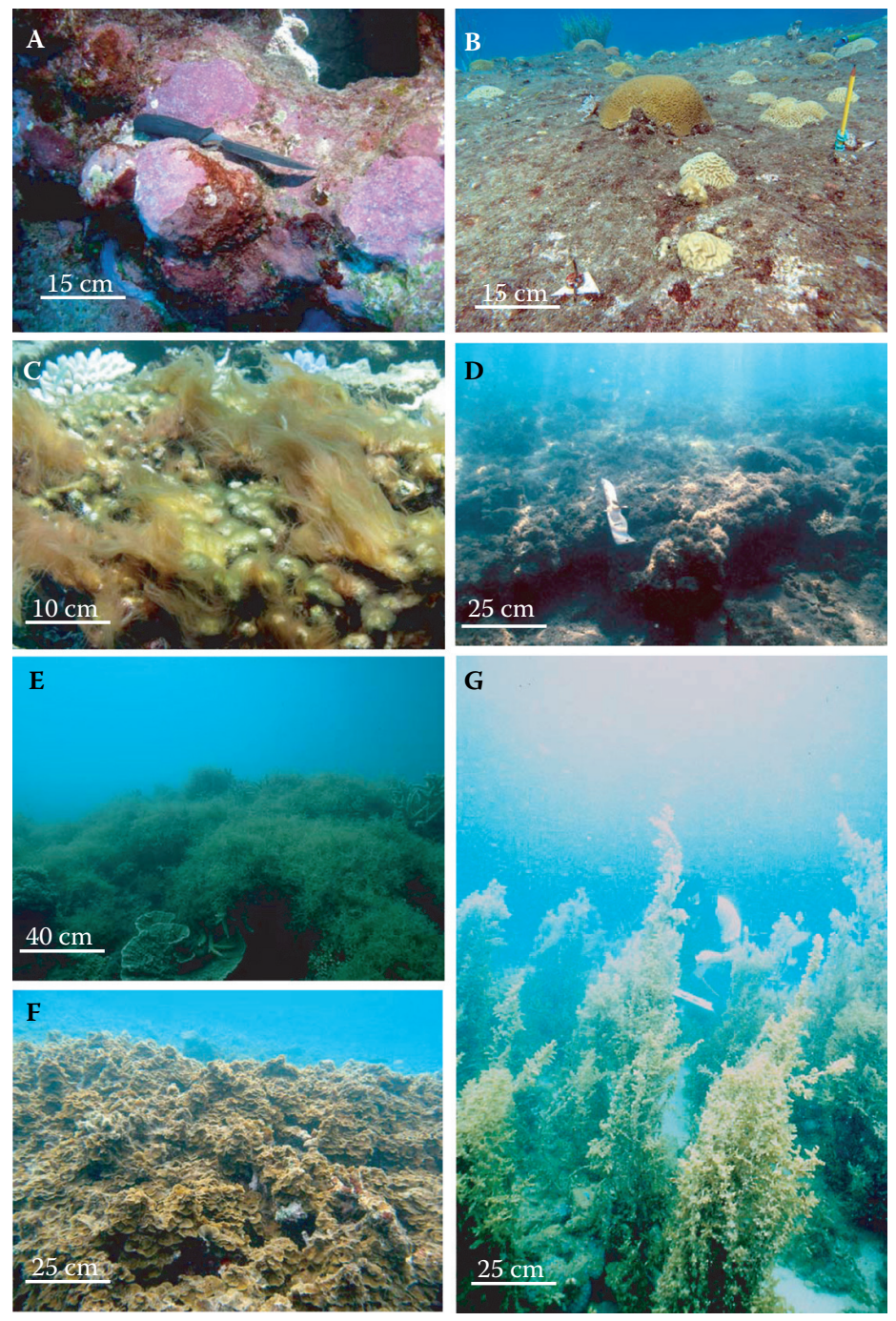

Colour Figure 1 (Birrell et al.) Different algal assemblages dominating reef habitats, creating large differences in the suitability of the habitat for coral replenishment. A. Crustose calcareous algae, especially from the Order Corallinales, form a calcified crust over the substratum and are generally associated with habitats that promote coral recruitment. B. Filamentous algal turfs, closely cropped by herbivorous fishes and sea urchins, create a low turf (1-5 mm in height), which is compatible with coral recruitment. C. Aggregations of Cyanobacteria (microalgae) may form longer filaments (30-100 $\mathrm{mm}$ in height) and often generate hostile chemical conditions. D. Thick mats of larger, more robust corticated algae may create a dense layer over much of the reef substratum (50-150 $\mathrm{mm}$ in height), trapping sediments and generating chemical and nutrient conditions that may be inimical to coral settlement and early recruits. E. A dense mat of the ephemeral, corticated brown alga, Chnoospora implexa, covering large areas of reef and live corals (up to $500 \mathrm{~mm}$ high). Because this mat was highly seasonal, and short-lived, it subsequently disappeared, with little apparent impact on the underlying corals. The impact of such a mat on coral replenishment would depend strongly on the timing of the bloom relative to coral spawning and settlement. F. Dense mat of the corticated, foliose brown alga, Lobophora variegata, covering corals killed during a mass bleaching event and rendering the substratum apparently inaccessible to coral recruits. G. Canopy of the leathery macrophyte, Sargassum (brown alga), which may reach heights of up to 3-4 m and densities of 100 plants $\mathrm{m}^{-2}$, pre-empting space for coral recruitment and significantly altering light and hydrodynamic regimes. 

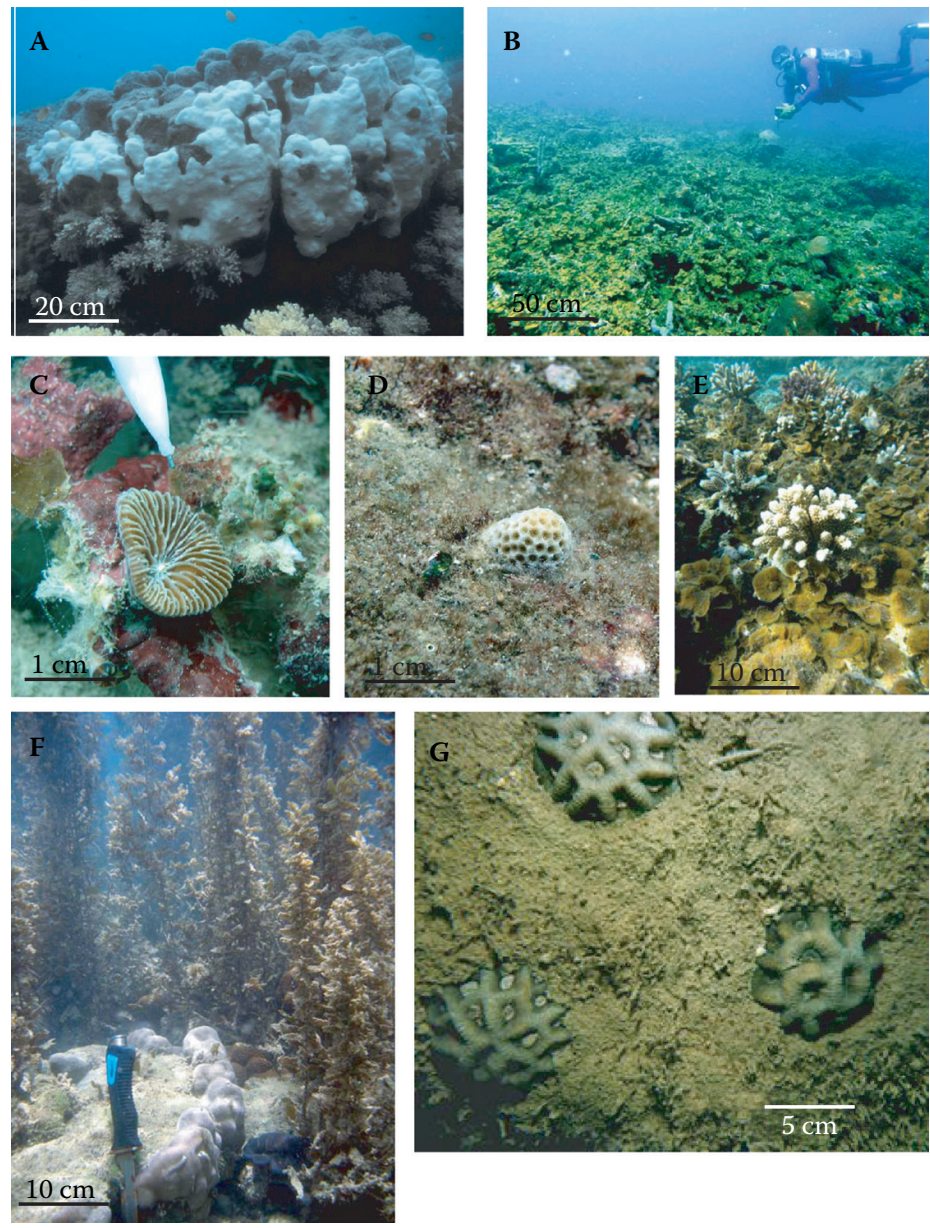

Colour Figure 2 (Birrell et al.) Disturbance, algal colonisation and effects of algae on coral recruitment. A. Colonisation of severely bleached coral tissue by fine filamentous algae. Disturbances that lead to coral tissue death usually result in colonisation of exposed coral skeleton by some form of benthic algae. Subsequent succession may result in very different algal assemblages, with very different consequences for coral replenishment. B. Overgrowth of damaged corals by the corticated, foliose brown alga, Lobophora variegata, has dramatically reduced substratum available for coral settlement. C. Healthy coral recruit attached to a crustose calcareous alga; such algae may enhance settlement of coral larvae. D. Coral recruit emerging from filamentous algal turf. The recruit would have been more strongly affected by physical and chemical conditions in the turf during settlement and early growth. E. Acropora corals emergent from a dense mat of Lobophora variegata (as in B and Figure 1F). F. Leathery macrophytes (e.g., Sargassum) may form an extensive canopy, but still retain significant understorey substratum suitable for coral settlement and recruitment, such as the filamentous turfs shown here. G. Trapping of sediments by filamentous algal turfs may enhance stress experienced by coral recruits and significantly reduce the suitability of habitat for their survival and growth. 